\title{
PANURGILLUS GÊNERO NOVO DE PANURGINAE, COM A DESCRIÇÃO DE QUATORZE ESPÉCIES DO SUL DO BRASIL (HYMENOPTERA, ANDRENIDAE) ${ }^{1}$
}

\author{
Clemens Schlindwein ${ }^{2}$ \\ Jesus Santiago Moure ${ }^{3}$
}

\begin{abstract}
Panurgillus, a new genus of Panurginae, with description of fourteen species from Southern Brazil (Hymenoptera, Andrenidae). Panurgillus, a generic name used by J.S. Moure throughout various years in litt. as a substitue of Panurginus in the Neotropical Apifauna, is formally described. All specimens of the species here described were collected during surveys of bees and melittophilous plants in th state of Rio Grande do Sul, southern Brazil. Various species of Panurgillus also occur in other states of southern Brazil, in Argentina and probably in Uruguay, Paraguay and Eastern Bolivia. The bees are small (3,9-7,4 mm), black, with generally a few yellow paintings, two submarginal cells, the 1st m-cu distant to the base of the second submarginal cell, the clypeus not projected, the facial foveae distinct, scopa with simple, long hairs and the gonobase absent. Panurginus vagabundus Cockerell, 1918 is transferred to Panurgillus as the type species and thirteen new species are described: $P$. eustictus, $P$. flavitarsis, $P$. formosus, $P$. guariticola, $P$. hamatus, $P$. harterae, $P$. holostictus, $P$. malvacearum, $P$. minutus, $P$. pereziae, $P$. plumosulus, $P$. politus and $P$. reticulatus. From some structures were took SEM photographs.

KEY WORDS. Hymenoptera, Apoidea, Andrenidae, Panurginae, Panurgillus, bee systematics, southern Brazil
\end{abstract}

Na região neotropical, a subfamília Panurginae é representada por mais de 20 gêneros (MichENER 1979), mas em várias partes da América do Sul a apifauna ainda é pouco conhecida. Levantamentos recentes de abelhas e de plantas melitófilas no Estado do Rio Grande do Sul mostraram que existem muitas espécies de abelhas ainda não descritas no sul do Brasil (WITTMANN \& HOFFMANN 1990; SCHLINDWEIN 1995; WiTTMANN \& SCHLINDWEIN 1995) e levaram a descrições de vários táxons novos (Moure \& CAMARgo 1989; CuRE \& WittManN 1990; URBAN 1992, 1995a,b, 1996).

Alguns gêneros e espécies novas de Panurginae foram descritos recentemente (Ruz 1991; Ruz \& RozEN 1993; Rozen \& RuZ 1995). Porém, ainda falta um estudo sistemático para a delimitar melhor a tribo Panurgini.

1) Contribuição número 1010 do Departamento de Zoologia, Universidade Federal do Paraná.

2) Institut für Landwirtschaftliche Zoologie und Bienenkunde, Universität Bonn. Melbweg 42 , D-53127 Bonn, Alemanha.

3) Departamento de Zoologia, Universidade Federal do Paraná. Caixa Postal 19020, 81531-990 Curitiba, Paraná, Brasil.

Revta bras. Zool. 15 (2): 397 - 439, 1998 
O nome Panurgillus foi usado por J.S. Moure desde 1956, porém sem descrição formal. Neste trabalho o gênero é descrito formalmente por J.S. Moure. São descritas 13 espécies novas e apresentada nova combinação e redescrição da espécie tipo Panurgillus vagabundus (Cockerell).

A maioria das espécies aqui descritas são oligolécticas (Tab. I). Porém, para algumas espécies ainda faltam dados abrangentes das flores visitadas. Pela ocorrência restrita em flores de poucas espécies de plantas, outras espécies de Panurgillus não descritas ainda podem aparecer.

\section{MATERIAL E MÉTODOS}

Os espécimes foram coletados durante levantamentos de abelhas e de plantas melitófilas por elas visitadas entre 1989 e 1996 em várias regiões do Estado do Rio Grande do Sul. Alguns espécimens de outras localidades do Sul do Brasil e da Argentina já se encontravam na Coleção J.S. Moure. As abelhas estão depositadas na "Coleção de Entomologia Pe. J.S. Moure", Universidade Federal de Paraná, Curitiba (DZUP); no Laboratório de Pesquisas Biológicas (LPB), Pontifícia Universidade Católica do Rio Grande do Sul, Porto Alegre; na Fundação Zoobotânica do Rio Grande do Sul (FZB), Porto Alegre; no Museu de Zoologia da Universidade de São Paulo (MZUSP), São Paulo; na coleção do Laboratório de Sistemática e Ecologia de Abelhas (LSEA), Departamento de Zoologia, Universidade Federal de Minas Gerais, Belo Horizonte e; na Coleção Entomológica do Departamento de Sistemática e Ecologia da Universidade Federal da Paraíba (UFPB), João Pessoa. Os dados de coleta foram arquivados em um banco de dados.

As micrografias foram feitas com um microscópio eletrônico de varredura "Cambridge Stereoscan $250 \mathrm{Mk2".} \mathrm{O} \mathrm{comprimento} \mathrm{dos} \mathrm{pêlos} \mathrm{é} \mathrm{aproximado,} \mathrm{medido}$ com aumento de 50 vezes; "pelos em gancho" foi a descrição mais facil para os pelos com as pontas recurvas existentes no lado ventral do mesepisterno de várias espécies. Os intervalos entre os pontos estão indicados pelo número de "dp" = "diâmetros de ponto" que os separam, assim um intervalo de três diâmetros de ponto é simplesmente indicado com $3 \mathrm{~d}$ p. Abreviaturas do texto são: $(\varnothing)$ diâmetro; $(\mathrm{C}+\mathrm{Sc})$ costa+subcosta, (T) tergo, (E) esterno.

\section{RESULTADOS E DISCUSSÃO}

\section{Panurgillus Moure gen.n.}

\section{Espécie tipo. Panurginus vagabundus Cockerell, 1918}

Diagnose. Trata-se de um Panurgini predominantemente preto com o clípeo não projetado para frente ou para baixo; as fóveas faciais evidentes, fundas e lisas, mais longas que largas; a escopa com cerdas simples, longas e esparsas; a pontuação fina, geralmente esparsa; o pronoto arredondado; escutelo, metanoto e área basal de propódeo no mesmo plano; a área basal do propódeo em geral com carenas, porém fracamente delimitada; T1 abaulado, sem grádulo, os demais tergos com depressões marginais destacadas; placa basitibial na fêmea e no macho rebordada, placa pigidial 
apenas na fềmea; asas com duas células submarginais o $1^{\circ} \mathrm{m}$-cu afastado da base da segunda célula submarginal; sem gonobase; E7 com a base em "V" muito aberto e o ápice muito alongado de lados subparalelos.

Descrição. Corpo pequeno (3,9-7,4 mm), predominantemente preto. Fêmeas sem desenhos amarelos no clípeo (com exceção de $P$. pereziae), machos com desenhos amarelos na face (com exceção de $P$. reticulatus e $P$. flavitarsis); geralmente com uma pequena mancha na base das tíbias anteriores e médias. Pubescência esparsa, curta e esbranquiçada.

Cabeça. Um pouco mais larga do que longa sem exceder notavelmente a largura do tórax; sem rebordo occipital; genas geralmente mais estreitas que os olhos de perfil; bordo inferior do ocelo médio coincidente com a tangente supraorbital; vértice convexo; alvéolos antenais aproximadamente no meio da face; áreas subantenais cerca de duas vezes sua largura, separadas apicalmente; fóvea tentorial localizada na entrada da sutura subantenal externa; fóvea facial bem marcada, longa, mais que duas vezes a sua largura, de fundo liso; o clípeo cerca de duas vezes mais largo que longo, moderadamente abaulado; labro mais curto que largo; placa labral completa, sobreposta, lisa, brilhante, às vezes com curtas rúgulas, subquadrada até bidentada; mandíbulas simples. Complexo lábio-maxilar de comprimento moderado; glossa aproximadamente tão longa como o pré-mento; artículo basal dos palpos labiais tão longo como os três seguintes juntos e estes subiguais entre si; parte distal da gálea cerca da metade da estípite, com o pente interno basal de 11 dentes; lacínia com cerdas não extraordinariamente grandes; palpos maxilares com seis artículos subiguais, mais longos do que o artículo basal dos palpos labiais; antenas semelhantes em ambos sexos; flagelo fracamente clavado, os artículos mais curtos do que largos menos o basal; o escapo um pouco mais longo que a metade do comprimento do flagelo e pedicelo juntos, quase igual ao comprimento alveolocelar; o pedicelo obpiriforme.

Tórax. Com o pronoto e o mesoscuto não carenados; pronoto curto; mesoscuto com a linha média evidente, as parapsidais fracas, finas e longas, as suturas prescutais vestigiais; o escutelo plano com o dobro do comprimento do metanoto, sem sulco ou depressão média; axila rebaixada; escroba mesepisternal reduzida a um ponto, o sulco prepisternal alongado, em geral trabeculado. Asas anteriores com duas células submarginais, a primeira maior do que a segunda; pterostigma grande, com o bordo inferior fortemente convexo, tão largo como o comprimento do prestigma; célula marginal um pouco mais longa que sua distância ao ápice, sua parte livre bem maior do que a ocupada pelas células submarginais, com o ápice obliquamente truncado, obsoletamente apendiculado; a $1^{\mathrm{a}} \mathrm{m}$-cu posterior ao $1^{\circ} \mathrm{r}-\mathrm{m}$; $1^{\text {a }}$ célula média curto-pedunculada; $1^{\text {a }} \mathrm{M}$ (veia basal) ligeiramente curva. Asa posterior com o lóbulo jugal longo, sobrepassando em um terço do seu comprimento a célula cubital; 6-12 hâmulos nas fêmeas, 5-9 nos machos. Pernas simples; esporão das pernas médias micro-denticulado (Fig. $5 \mathrm{~d}$ ), um pouco mais curto que o basitarso respectivo, claramente mais longo que os esporões posteriores; estes curtos, denticulados terminando em ponta; placa basitibial presente nos dois sexos, rebordada, glabra no macho, rebordada e com pilosidade especial nos dois terços basais na fêmea (Fig. 5b); basitarso posterior maior do que o médio; a escopa na tíbia posterior 
formada por cerdas simples, longas, relativamente esparsas e curvas; unhas bidentadas, arólio grande, quase tão longo como os dentes da unha.

Abdômen. No propódeo, o sulco posterior no fundo de uma depressão; limites da área basal pouco definidos; área basal com carenas em geral subparalelas até irregulares. Metasoma não pedunculado; a parte horizontal posterior do primeiro tergo contínua com a anterior em curva suave, sem grádulo; fóveas laterais no T2 em geral fracamente desenvolvidas em ambos sexos; depressões marginais bem marcadas em T1-T4 na fêmea e em T1-T6 no macho; T6 da fêmea com placa pigidial rebordada, parabolóide, a parte média um pouco elevada e geralmente com rugas transversais; no macho 5 esternos expostos, até E5 normal; E6 bilobado; E7 com a parte basal em "V" muito aberto e os lóbulos posteriores subparalelos, agudos, separados até a base; E8 bastante robusto.

Cápsula genital um pouco mais longa que larga, gonobase ausente; os gonóstilos fundidos com os gonocoxitos, um pouco mais curtos que as valvas; as valvas fundidas entre si, agudas distalmente, soldadas ao pênis; volselas bem desenvolvidas, com dígito e cúspide distintos, com dentículos.

Panurgillus separa-se facilmente de Panurginus Nylander, 1848, pela venação da asa anterior $\left(1^{\circ} \mathrm{m}\right.$-cu afastado da base da segunda célula submarginal), pela fóvea facial muito rasa e pela área subantenal curta em Panurginus. Panurgillus assemelha-se aos gêneros Anthrenoides, Cephalurgus, Chaeturginus e Rhophitulus. Anthrenoides Ducke, 1907, difere por ter três células submarginais e pelo tamanho maior. Cephalurgus Moure \& Oliveira, 1962, distingue-se pela largura da cabeça, pela fóvea facial pequena no macho, pelas áreas subantenais curtas, pela área basal do propódeo lisa e bem delimitada por forte sulco e pela presença de gonobase. Chaeturginus Oliveira \& Moure, 1963, distingue-se pelas espículas excepcionais nos esternos para coletar pólen, peças bucais, e área subantenal convergente em baixo. Rhophitulus Ducke, 1907, difere pela saliência do clípeo, comprimento da língua e dos palpos labiais.

Etimologia. Panurgillus é um diminutivo de Panurginus por serem estas abelhas de tamanho menor.

Distribuição. Sul do Brasil, Argentina. Provavelmente ocorre também em outras regiões do Brasil, no Uruguai, Paraguay e Leste da Bolívia.

\section{Panurgillus eustictus sp.n.}

Diagnose. Mandíbulas castanhas; base das tíbias anteriores e médias com mancha amarela; olhos subparalelos; placa labral larga, quase truncada, pilosidade muito curta no mesoscuto; pêlos em gancho no lado ventral dos mesepisternos; clípeo liso entre os pontos, a margem anterior quase sem pontos; pontuação no vértice profunda, no T1-T4 fina e densa.

Holótipo fêmea. Comprimento total aproximado $5,0 \mathrm{~mm}$; asa anterior 4,4 $\mathrm{mm}$; largura da cabeça $1,58 \mathrm{~mm}$; comprimento da cabeça $1,4 \mathrm{~mm}$; largura do metasoma $1,6 \mathrm{~mm}$.

Tegumento preto; mandíbulas ocres de ápices pretos; antena amarela por 
baixo; tégula ocre, translúcida, como o esclerito costal; asas subhialinas, levemente esfumaçadas, com as veias e o pterostigma pardo-méleos; uma mancha amarela na base da $\mathrm{C}+\mathrm{Sc}$; os três pares de pernas castanho-escuros, os tarsos ocres; uma mancha amarela pequena na base das tíbias anteriores e médias; depressões marginais pretas.

Pilosidade esbranquiçada rala, nos tarsos amarelada; curta na face, nas genas e no vértice (cerca de $0,14 \mathrm{~mm}$ ); no mesoscuto curta $(0,06 \mathrm{~mm})$; no escutelo, metanoto e nos mesepisternos mais plumosa e mais longa (cerca de $0,26 \mathrm{~mm}$ ); face ventral do mesepisterno com pêlos finos em gancho; escopa inteiramente branca com cerdas não plumosas (até $0,4 \mathrm{~mm}$ ); nos flancos do propódeo comprida como nos mesepisternos; comprimento dos pêlos no T5 $0,3 \mathrm{~mm}$, franjas apicais de pêlos escuros; pêlos no escapo até $0,08 \mathrm{~mm}$.

Pontuação muito densa na fronte $(\varnothing 0,02-0,03 \mathrm{~mm}$, cerca de $1 / 2 \mathrm{dp})$ os intervalos reticulados; mais esparsa nas áreas paroculares, supraclipeal e clípeo (até $3 \mathrm{dp}$ ), tornando-se mais esparsa para a margem anterior, os intervalos lisos; área ocelorbital quase sem pontos perto do ocelo, como na área interocelar, porém com retículo forte; no vértice densa os pontos profundos, mais rasos nas genas e os intervalos lisos. No mesoscuto fina ( $\varnothing$ cerca de $0,02 \mathrm{~mm}$ ), esparsa (1-2dp, alguns intervalos maiores), os intervalos reticulados; no escutelo e metanoto mais esparsa, os pontos mais grossos que no mesoscuto, os intervalos reticulados; nos mesepisternos 1-2dp, adensando-se para cima, os intervalos fortemente reticulados; nos metepisternos com retículo forte; nos cantos laterais e face posterior do propódeo fina e densa, desaparecendo nos cantos posteriores, passando a reticulada junto a área basal; nos tergos muito fina e relativamente densa, tornando-se esparsa em direção às depressões marginais, os intervalos fracamente reticulados; tamanho dos pontos diminuindo de T1 até T4; em T5 grossa e muito esparsa; as depressões marginais dos tergos micropontuadas.

Comprimento do olho $0,9 \mathrm{~mm}$, largura $0,42 \mathrm{~mm}$; olhos paralelos, distâncias interorbitais: superior $1 \mathrm{~mm}$, média $1 \mathrm{~mm}$, inferior $0,96 \mathrm{~mm}$; distância interalveolar $0,26 \mathrm{~mm}$; alveolorbital $0,24 \mathrm{~mm}$; alveolocelar $0,42 \mathrm{~mm}$; $\varnothing$ alvéolo $0,12 \mathrm{~mm}$; interocelar $0,22 \mathrm{~mm}$; ocelorbital $0,32 \mathrm{~mm}$; $\varnothing$ ocelo médio $0,12 \mathrm{~mm}$; comprimento das suturas subantenais: a externa $0,34 \mathrm{~mm}$, a interna $0,28 \mathrm{~mm}$, largura da área subantenal $0,11 \mathrm{~mm}$; comprimento do clípeo $0,42 \mathrm{~mm}$, largura $0,9 \mathrm{~mm}$; clipeocelar $0,7 \mathrm{~mm}$; linha frontal em forma de sulco, pouco evidente no terço superior; fóvea facial bem marcada, estreita, um pouco alargada na metade superior, lisa, mate, comprimento $0,3 \mathrm{~mm}$ largura $0,09 \mathrm{~mm}$; largura do labro $0,46 \mathrm{~mm}$, placa labral lisa, sem rúgulas, quase truncada, os lados um pouco convergentes para o ápice, comprimento $0,22 \mathrm{~mm}$, largura $0,3 \mathrm{~mm}$; escapo: comprimento e $\varnothing$ máximo $0,34 \mathrm{~mm}$, $0,1 \mathrm{~mm}$; flagelo clavado, comprimento dos três primeiros flagelômeros $0,12 \mathrm{~mm}$, $0,07 \mathrm{~mm}, 0,08 \mathrm{~mm}, \varnothing$ do terceiro $0,14 \mathrm{~mm}, \varnothing$ máximo $0,16 \mathrm{~mm}$; flagelo e pedicelo juntos $1,38 \mathrm{~mm} ; 7$ a 8 hâmulos, fêmur médio em arco levemente anguloso; basitarso médio duas vezes mais longo que largo $(0,4: 0,2 \mathrm{~mm})$; área basal do propódeo semi-lunar com carenas curtas, subparalelas, a média como as transversais, não alcançando a margem posterior do propódeo; fóveas laterais no T2 pouco evidentes, com os bordos indefinidos, comprimento cerca de $0,24 \mathrm{~mm}$, largura $0,12 \mathrm{~mm}$; placa pigidial ligeiramente rebordada, com estrias transversais muito evidentes. 
Holótipo fêmea. BRAsil, Rio Grande do Sul: Caçapava do Sul (Guaritas), 26-X-1991, C. Schlindwein leg. (DZUP). Parátipos com os mesmos dados do holótipo, 1 fềmea (LPB) e 1 fềmea (LSEA).

Flores visitadas. Oxalis niederleinii Knuth (Oxalidaceae).

Sazonalidade. Outubro

Distribuição geográfica. BRASIL: Rio Grande do Sul, Serra do Sudeste.

Etimologia. $\varepsilon \cup \dot{U}=$ muito, $\sigma \tau \iota \kappa \tau o s=$ pontuados. Refere-se à pontuação profunda no vértice.

Comentário. Assemelha-se a $P$. holostictus, $P$. vagabundus e $P$. hamatus, mas difere pelas mandíbulas castanhas e intervalos mate-reticulados entre os pontos em T1.

\section{Panurgillus malvacearum sp.n.}

Figs $1 a-b, 2 d, 3 c, 5 d$

Diagnose. Clípeo fortemente reticulado como todo o corpo; pernas inteiramente pretas; mespisternos no lado ventral sem pêlos em gancho; pontuação fina e densa no T1-T4; olhos paralelos; pêlos no mesoscuto muito curtos; fêmures médios com face ventral em curva contínua; 9 a 10 hâmulos.

Holótipo fêmea. Comprimento total aproximado $6,8 \mathrm{~mm}$; asa anterior 5,5 $\mathrm{mm}$; largura da cabeça $2,1 \mathrm{~mm}$; comprimento da cabeça $1,88 \mathrm{~mm}$; largura do metasoma $2,06 \mathrm{~mm}$.

Tegumento preto, flagelo amarelo-pálido por baixo; tégula amarela, translúcida, preta no terço anterior; asas subhialinas com veias e pterostigma castanhoclaros, uma pequena mancha amarela na base $\mathrm{da} \mathrm{C}+\mathrm{Sc}$; pernas inteiramente pretas; depressões marginais dos tergos fracamente translúcidas na margem posterior, quase inteiramente pretas.

Pilosidade esbranquiçada, esparsa e rala; no vértice e na face $0,2 \mathrm{~mm}$; no pronoto e nos lóbulos curta, plumosa e densa; no mesoscuto muito curta $(0,06 \mathrm{~mm})$, adpressa, mais comprida no escutelo e no metanoto; pêlos plumosos nos mesepisternos até $0,24 \mathrm{~mm}$, no lado ventral sem pêlos em gancho; pêlos da escopa brancos, não plumosos esparsos, comprimento cerca de $0,5 \mathrm{~mm}$; nos flancos do propódeo um pouco mais curta que nos mesepisternos; cerdas no T5 pretas na base, até 0,5 $\mathrm{mm}$; T5 com curta franja apical escura; pêlos no escapo até $0,12 \mathrm{~mm}$.

Pontuação grossa na fronte $(\varnothing 0,03-0,04 \mathrm{~mm})$ e densa, $(\leq 1 \mathrm{dp})$, muito densa entre os alvéolos; na metade inferior abaixo dos alvéolos mais grossa, especialmente no clípeo ( $\varnothing$ até $0,06 \mathrm{~mm}$ ), e um pouco mais esparsa (cerca de $1 \mathrm{dp}$ ); os intervalos entre os pontos fortemente reticulados em todo o corpo; no mesoscuto mais fina que na face (cerca de 0,02 mm), relativamente densa (1dp), no escutelo e metanoto um pouco mais grossa; os metepisternos fortemente reticulados; mais evidente, fina e densa na parte anterior dos flancos do propódeo como nos metepisternos, na parte posterior dos flancos e na face posterior do propódeo; nos tergos fina e densa (cerca de $1 \mathrm{dp}$ ), ficando mais esparsa próximo das depressões marginais; em T5 mais grossa e mais esparsa (2-3dp); depressões marginais dos tergos micropontuadas. 

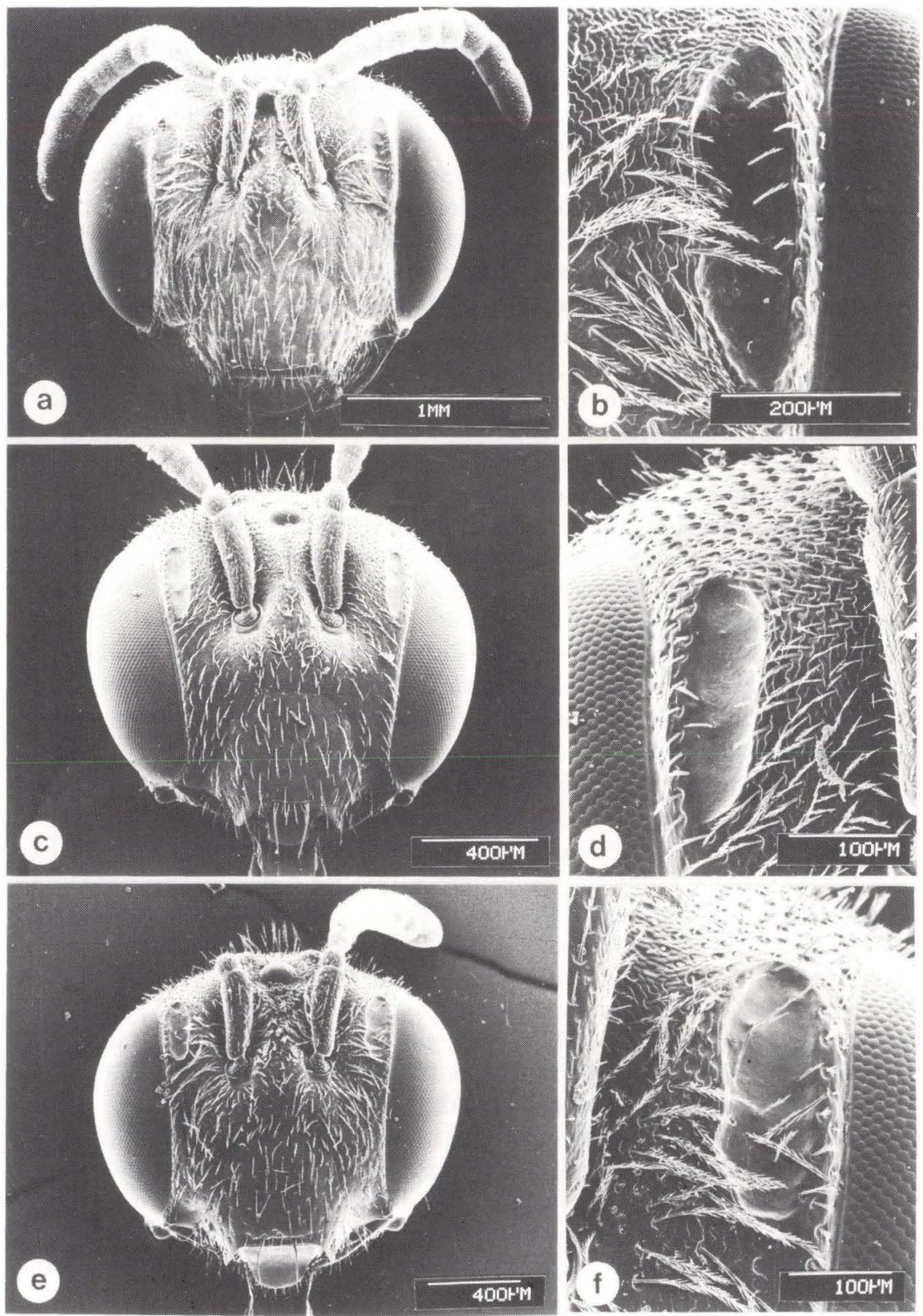

Fig. 1. Cabeça e fóvea facial. (a-b) Panurgillus malvacearum; (c-d) P. minutus; (e-f) P. pereziae. 
Comprimento do olho $1,24 \mathrm{~mm}$, largura $0,62 \mathrm{~mm}$; distâncias interorbitais: superior $1,34 \mathrm{~mm}$, média $1,3 \mathrm{~mm}$, inferior $1,34 \mathrm{~mm}$; distância interalveolar 0,34 $\mathrm{mm}$; alveolorbital $0,32 \mathrm{~mm}$; alveolocelar $0,56 \mathrm{~mm}$; $\varnothing$ alvéolo $0,14 \mathrm{~mm}$; interocelar $0,36 \mathrm{~mm}$; ocelorbital $0,36 \mathrm{~mm} ; \varnothing$ ocelo médio $0,18 \mathrm{~mm}$; curtas carenas radiantes em volta do ocelo médio; comprimento das suturas subantenais: a externa $0,46 \mathrm{~mm}$, a interna $0,32 \mathrm{~mm}$, largura da área subantenal $0,16 \mathrm{~mm}$; comprimento do clípeo 0,6 $\mathrm{mm}$, largura 1,26 mm; uma carena ao longo do clípeo extendendo-se até a área supraclipeal, podendo faltar; clipeocelar $0,84 \mathrm{~mm}$; linha frontal fortemente careniforme; fóvea facial (Fig. 1b) comprida e estreita, largura máxima na metade superior $0,14 \mathrm{~mm}$, comprimento $0,42 \mathrm{~mm}$, com alguns pontos pilígeros; largura do labro 0,64 $\mathrm{mm}$, placa labral curta, em arco rebaixado, lisa e com vestígios de rúgulas radiantes (Fig. 3c), comprimento $0,3 \mathrm{~mm}$, largura $0,4 \mathrm{~mm}$; escapo: comprimento e $\varnothing$ máximo $0,56 \mathrm{~mm}, 0,14 \mathrm{~mm}$; flagelo ligeiramente clavado, comprimento dos três primeiros flagelômeros $0,2 \mathrm{~mm}, 0,12 \mathrm{~mm}, 0,12 \mathrm{~mm}, \varnothing$ do terceiro $0,16 \mathrm{~mm}$, maior $\varnothing 0,2 \mathrm{~mm}$; flagelo e pedicelo juntos $1,98 \mathrm{~mm} ; 9$ a 10 hâmulos; fêmur médio com ângulo obtuso sem formar saliências; basitarso médio 2-3 vezes mais longo que largo; área basal do propódeo semilunar, muitas carenas curtas, subparalelas, a carena média mais forte que as laterais, irregular, alcançando a margem posterior do propódeo, o canto posterior do propódeo sem rúgulas e pontos, mas com retículo forte, além disso uma linha demarcando uma área maior somente reticulada, que termina na fóvea posterior do propódeo; T2 com fóveas laterais pouco evidentes, comprimento $0,44 \mathrm{~mm}$, largura $0,17 \mathrm{~mm}$; placa pigidial com estrias transversais pouco evidentes na porção mediana, porém faltando na parte posterior, as margens levemente elevadas.

Macho não conhecido.

Holótipo fêmea. Brasil, Rio Grande do Sul: Caçapava do Sul (Guaritas), 14-X-1992, C. Schlindwein leg. Parátipos da mesma localidade e coletor do holótipo, 25-X-1990, 1 fềmea; 11-XI-1990, três fêmeas; da mesma localidade, 22-X-1994, Mardiore Pinheiro leg., 1 fêmea (DZUP); parátipos da mesma localidade e coletor do holótipo, 01-X-1990, 1 fêmea; 25-X-1990, 10 fêmeas; 11-XI1990, 4 fêmeas; 13-X-1991, duas fêmeas; 30-IX-1992, duas fêmeas; 10-X-1992, 1 fêmea; 14-X-1992, 1 fêmea; 25-X-1992, 1 fêmea; 7-X-1993; 5 fêmeas; 08-X-1993, 4 fêmeas; 10-X-1993, 1 fêmea; da mesma localidade do holótipo, 25-X-1990, B. Hiller leg., 6 fềmeas; 25-X-1990, S. W. Freitas leg., 4 fềmeas (LPB); parátipos da mesma localidade e coletor do holótipo, 08-X-1993, três fêmeas; 21-X-1994, 1 fêmea (FZB); parátipos da mesma localidade e coletor do holótipo, 25-X-1990, 4 fêmeas; 11-XI-1990, 3 fềmeas (MZUSP); parátipos com os mesmos dados do holótipo, 1 fêmea; da mesma localidade e coletor, 25-X-1990, três fêmeas; 08-X1991, 1 fềmea; 13-X-1991, 1 fềmea; 30-IX-1992, 1 fềmea; 23-X-1992, 1 fềmea; 08-X-1993, duas fêmeas, 21-X-1994, 1 fêmea (UFPB); parátipos da mesma localidade e coletor, 25-X-1990, 1 fềmea; 08-X-1993, 1 fềmea; 10-X-1993, 1 fềmea (LSEA).

Flores visitadas. Cerastium commersonianum Ser. (Caryophyllaceae), Croton thermarum Muller Argoviensis (Euphorbiaceae); Glechon thymoides Spreng. (Lamiaceae), Abutilon terminale (Cav.) St.Hil., Modiolastrum lateritium (Hook.) Krapovickas (Malvaceae). 
Sazonalidade. Outubro e novembro.

Distribuição geográfica. Brasil, Rio Grande do Sul, Serra do Sudeste (Guaritas).

Etimologia. O nome é alusivo as plantas preferencialmente visitadas
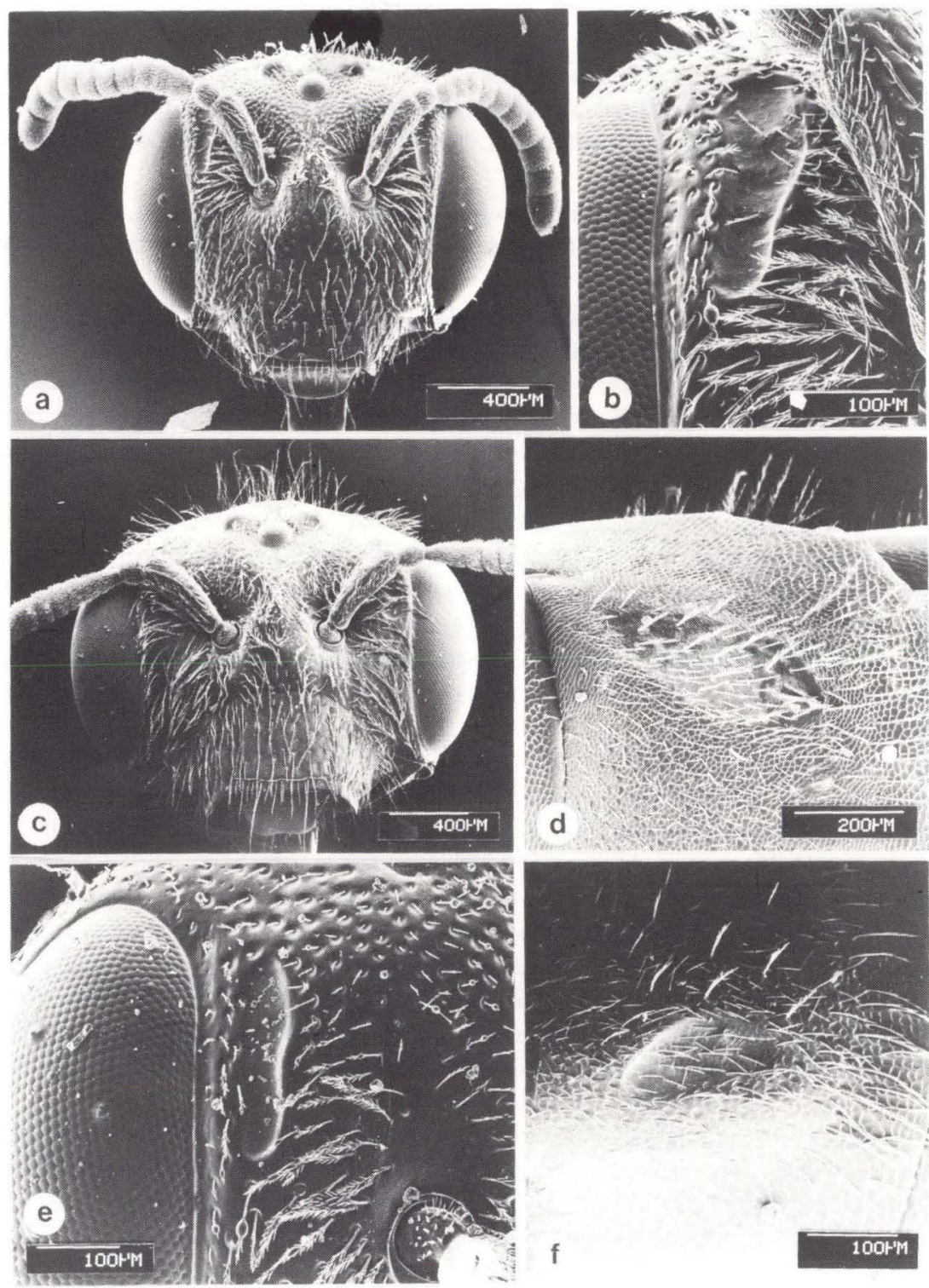

Fig. 2. Panurgillus vagabundus: (a) cabeça, (b) fóvea facial; (c) $P$. flavitarsis: (d) cabeça; $P$ malvacearum: (e) fóvea lateral no T2; $P$. hamatus (f) fóvea facial; $P$. minutus fóvea lateral no T2. 


\section{Panurgillus minutus sp.n.}

Figs 1c-d, 2f, 3d, 4b

Diagnose. A fêmea com os lóbulos pronotais com pequena mancha amarela; tíbias anteriores e médias com uma mancha amarela na base; pontuação esparsa na área ocelorbital, densa no mesoscuto e no T1-T4; olhos convergentes para baixo; placa labral estreita, tão longa quanto larga; mesoscuto com pêlos curtos; pêlos em gancho na face ventral dos mesepisternos; fêmur médio com dente na face ventral; T2 com fóveas laterais bem marcadas, profundas. O macho com a placa labral triangular, pequena.

Holótipo fêmea. Comprimento total aproximado $4,7 \mathrm{~mm}$; asa anterior 3,5 $\mathrm{mm}$; largura da cabeça $1,54 \mathrm{~mm}$; comprimento da cabeça $1,26 \mathrm{~mm}$; largura do metasoma $1,48 \mathrm{~mm}$.

Tegumento preto com as mandíbulas castanho-escuras; o flagelo amarelo por baixo; mancha amarela pequena nos lóbulos pronotais; tégula ocre, translúcida; asas ligeiramente fuscas, veias e pterostigma méleos, uma pequena mancha amarela na base da $\mathrm{C}+\mathrm{Sc}$; uma estria amarela até quase a metade da tíbia anterior, uma mancha amarela na base das tíbias médias; tarsos de todos os pares ocres; depressões marginais dos tergos fracamente translúcidas.

Pilosidade esbranquiçada, rala e curta; na face, no vértice e nas genas cerca de $0,1 \mathrm{~mm}$; muito curta no mesoscuto (cerca de $0,04 \mathrm{~mm}$ ), um pouco mais comprida no escutelo e no metanoto; um pouco mais evidente e plumosa nos mesepisternos $(0,2 \mathrm{~mm})$, no lado ventral com pêlos finos em gancho (Fig. 4b); escopa inteiramente branca com cerdas pouco plumosas, moderadamente numerosas, comprimento cerca de $0,34 \mathrm{~mm}$; no T5 $0,35 \mathrm{~mm}$ e com curta franja apical preta; pêlos no escapo até $0,08 \mathrm{~mm}$.

Pontuação na fronte fina e densa (cerca de $0,02, \mathrm{~mm}<1 \mathrm{dp}$ ), os intervalos reticulados; na metade inferior da face mais grossa (até $0,04 \mathrm{~mm}$ ) e mais esparsa, (até $3 \mathrm{dp}$ ), os intervalos finamente reticulados, o retículo quase desaparecendo no clípeo, com alguns micropontos intercalados; nas genas e no vértice fina, os intervalos reticulados, cerca de $1 \mathrm{dp}$; no mesoscuto fina $(0,02 \mathrm{~mm})$ e densa $(<1 \mathrm{dp})$, os intervalos reticulados; no escutelo e metanoto um pouco mais grossa e um pouco mais esparsa que no mesoscuto; os flancos do propódeo com micropontuação e nos cantos com pontuação mais definida e densa, desaparecendo em direção à área basal do propódeo, intervalos reticulados; nos tergos fina e relativamente densa (cerca de 1dp), ficando mais esparsa em direção à depressão marginal, em T5 mais grossa e esparsa; depressões marginais micropontuadas.

Comprimento do olho $0,92 \mathrm{~mm}$, largura $0,52 \mathrm{~mm}$; olhos convergentes para baixo, distâncias interorbitais: superior $1,08 \mathrm{~mm}$, média $0,92 \mathrm{~mm}$, inferior $0,78 \mathrm{~mm}$; distância interalveolar $0,24 \mathrm{~mm}$; alveolorbital $0,24 \mathrm{~mm}$; alveolocelar $0,46 \mathrm{~mm} ; \varnothing$ alvéolo $0,13 \mathrm{~mm}$; interocelar $0,25 \mathrm{~mm}$; ocelorbital $0,32 \mathrm{~mm}$; $\varnothing$ ocelo médio 0,14 $\mathrm{mm}$; comprimento das suturas subantenais: a externa $0,35 \mathrm{~mm}$, a interna $0,26 \mathrm{~mm}$, largura da área subanteanal $0,12 \mathrm{~mm}$; comprimento do clípeo $0,42 \mathrm{~mm}$, largura 0,76 $\mathrm{mm}$; clipeocelar $0,70 \mathrm{~mm}$; linha frontal sulciforme entre as antenas, na metade superior até o ocelo médio pouco evidente; fóvea facial (Fig. 1d) estreita e longa, 


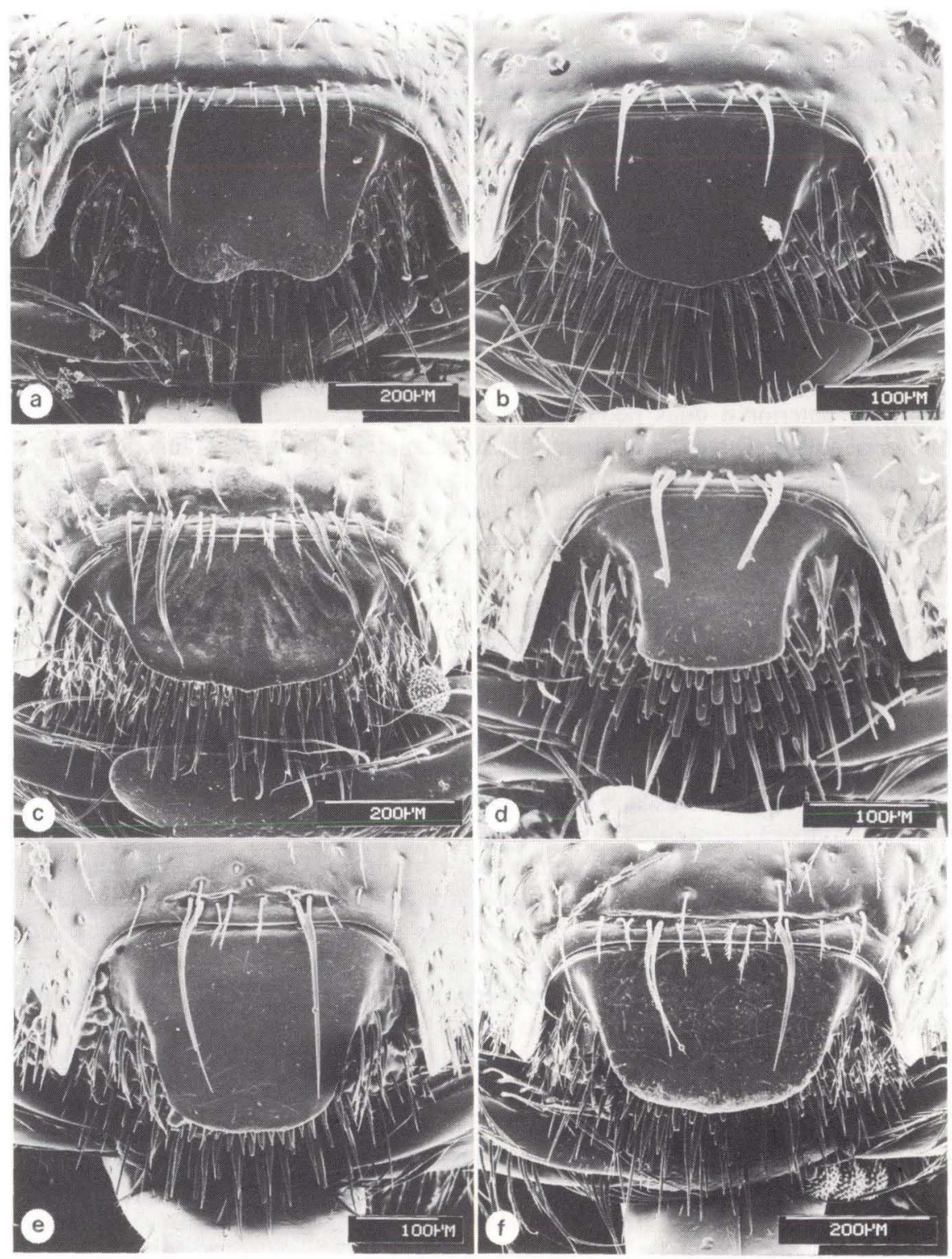

Fig. 3. Labro e placa labral. (a) Panurgillus flavitarsis, (b) P. hamatus; (c) P. malvacearum; (d) P. minutus; (e) P. pereziae; (f) P. vagabundus.

bem marcada, lisa, comprimento $0,26 \mathrm{~mm}$, largura $0,06 \mathrm{~mm}$; largura do labro 0,34 $\mathrm{mm}$, placa labral pequena, lisa, sem rúgulas, tão longa como larga (Fig. 3d), comprimento $0,18 \mathrm{~mm}$, largura $0,18 \mathrm{~mm}$; escapo: comprimento e $\varnothing$ máximo 0,38 $\mathrm{mm}, 0,1 \mathrm{~mm}$; flagelo ligeiramente clavado, comprimento dos três primeiros flagelômeros $0,13 \mathrm{~mm}, 0,08 \mathrm{~mm}, 0,10 \mathrm{~mm}, \varnothing$ do terceiro $0,14 \mathrm{~mm}, \varnothing$ máximo $0,17 \mathrm{~mm}$; 
flagelo e pedicelo juntos $1,32 \mathrm{~mm} ; 8$ hâmulos; fêmur médio com ângulo bem marcado, agudo, com ponta fina; basitarso médio duas vezes mais longo que largo $(0,42: 0,2 \mathrm{~mm})$; área basal do propódeo semilunar com rúgulas fortes, subparalelas, um pouco irregulares para o ápice, a média alcançando o canto posterior do propódeo, as laterais mais curtas; T2 com fóveas laterais bem marcadas (Fig. 2f), comprimento $0,24 \mathrm{~mm}$, largura $0,11 \mathrm{~mm}$; placa pigidial rebordada, lisa, com carena média rebaixada.

Alótipo macho. Comprimento total aproximado $4,6 \mathrm{~mm}$; asa anterior 3,3 $\mathrm{mm}$; largura da cabeça $1,46 \mathrm{~mm}$; comprimento da cabeça $1,2 \mathrm{~mm}$; largura do metasoma $1,1 \mathrm{~mm}$.

Tegumento preto, o clípeo amarelo, menos uma estreita faixa escura na margem anterior e duas pequenas manchas pretas, simétricas, perto da fóvea tentorial anterior; áreas paroculares inferiores amarelas quase até a tangente inferior dos alvéolos antenais; mandíbulas castanho-claras, um pouco translúcidas; flagelo amarelo; tégula translúcida, amarelada; lóbulos pronotais amarelos; asas subhialinas com veias e pterostigma castanho-claros, a base da $\mathrm{C}+\mathrm{Sc}$ amarela; extremidade apical dos fêmures com uma pequena mancha amarela; tíbia anterior amarela, escurecida por detrás; tíbia média com uma estria amarela na extremidade basal; tíbia posterior com a metade basal amarela, inclusive a placa basitibial; tarsos dos três pares de pernas amarelos; depressões marginais dos tergos claras, translúcidas.

Pilosidade esbranquiçada, esparsa, rala; na face, no vértice e nas genas até $0,16 \mathrm{~mm}$; no mesoscuto e no escutelo curta (cerca de $0,06 \mathrm{~mm}$ ); um pouco mais comprida no metanoto e nos mesepisternos; E3 até E5 com pêlos adpressos inconspícuos; pêlos no escapo até $0,1 \mathrm{~mm}$.

Pontuação densa na fronte, na área supraclipeal e subantenal (cerca de 1dp, $\varnothing 0,02-0,03 \mathrm{~mm}$ ), um pouco mais esparsa no clípeo, um pouco mais densa no vértice; no mesoscuto densa ( $\leq 1 \mathrm{dp}, \varnothing$ cerca de $0,02 \mathrm{~mm}$ ), os intervalos reticulados; no escutelo e no metanoto um pouco mais grossa e esparsa, retículo no metanoto muito evidente; nos mesepisternos densa, os intervalos fortemente retículados; nos metepisternos muito fina e densa; propódeo sem pontos junto à área basal, porém com retículo forte, nos flancos como nos metepisternos; em T1-T5 relativamente densa ( $\leq 1 \mathrm{dp}$ ), mais esparsa em direção às depressões marginais, $\varnothing$ diminuindo de $\mathrm{T} 1$ para $\mathrm{T} 5$, os intervalos reticulados, $\mathrm{T} 6$ com pontos grossos; depressões marginais micropontuadas, desaparecendo no T5 e T6.

Comprimento do olho $0,86 \mathrm{~mm}$, largura $0,5 \mathrm{~mm}$; olhos convergentes para baixo, distâncias interorbitais: superior $1,0 \mathrm{~mm}$, média $0,8 \mathrm{~mm}$, inferior $0,72 \mathrm{~mm}$; distância interalveolar $0,2 \mathrm{~mm}$; alveolorbital $0,18 \mathrm{~mm}$; alveolocelar $0,4 \mathrm{~mm} ; \varnothing$ alvéolo $0,13 \mathrm{~mm}$; interocelar $0,24 \mathrm{~mm}$; ocelorbital $0,3 \mathrm{~mm}$; $\varnothing$ ocelo médio 0,11 $\mathrm{mm}$; suturas subantenais: a externa $0,3 \mathrm{~mm}$, a interna $0,24 \mathrm{~mm}$, largura da área subantenal $0,1 \mathrm{~mm}$; comprimento do clípeo $0,42 \mathrm{~mm}$, largura $0,7 \mathrm{~mm}$; clipeocelar $0,58 \mathrm{~mm}$; linha frontal pouco evidente, sulciforme até o ocelo médio; fóvea facial curta, estreita, lisa, bem marcada, comprimento $0,14 \mathrm{~mm}$, largura 0,04 $\mathrm{mm}$; largura do labro $0,28 \mathrm{~mm}$, placa labral triangular, muito pequena, lisa, comprimento 0,1 $\mathrm{mm}$, largura $0,12 \mathrm{~mm}$; comprimento e $\varnothing$ máximo do escapo $0,3 \mathrm{~mm}, 0,14 \mathrm{~mm}$; comprimento dos três primeiros flagelômeros $0,12 \mathrm{~mm}, 0,09 \mathrm{~mm}, 0,1 \mathrm{~mm}, \varnothing$ do terceiro $0,12 \mathrm{~mm}$, maior $\varnothing 0,16 \mathrm{~mm}$; flagelo e pedicelo juntos $1,46 \mathrm{~mm} ; 7$ hâmulos; 
comprimento do basitarso médio 0,4 $\mathrm{mm}$, largura, 0,08 $\mathrm{mm}$; área basal do propódeo semilunar, com curtas carenas evidentes, subparalelas até vermiculadas; T2 com fóveas laterais pequenas, ovais, evidentes, comprimento $0,1 \mathrm{~mm}$, largura $0,06 \mathrm{~mm}$.
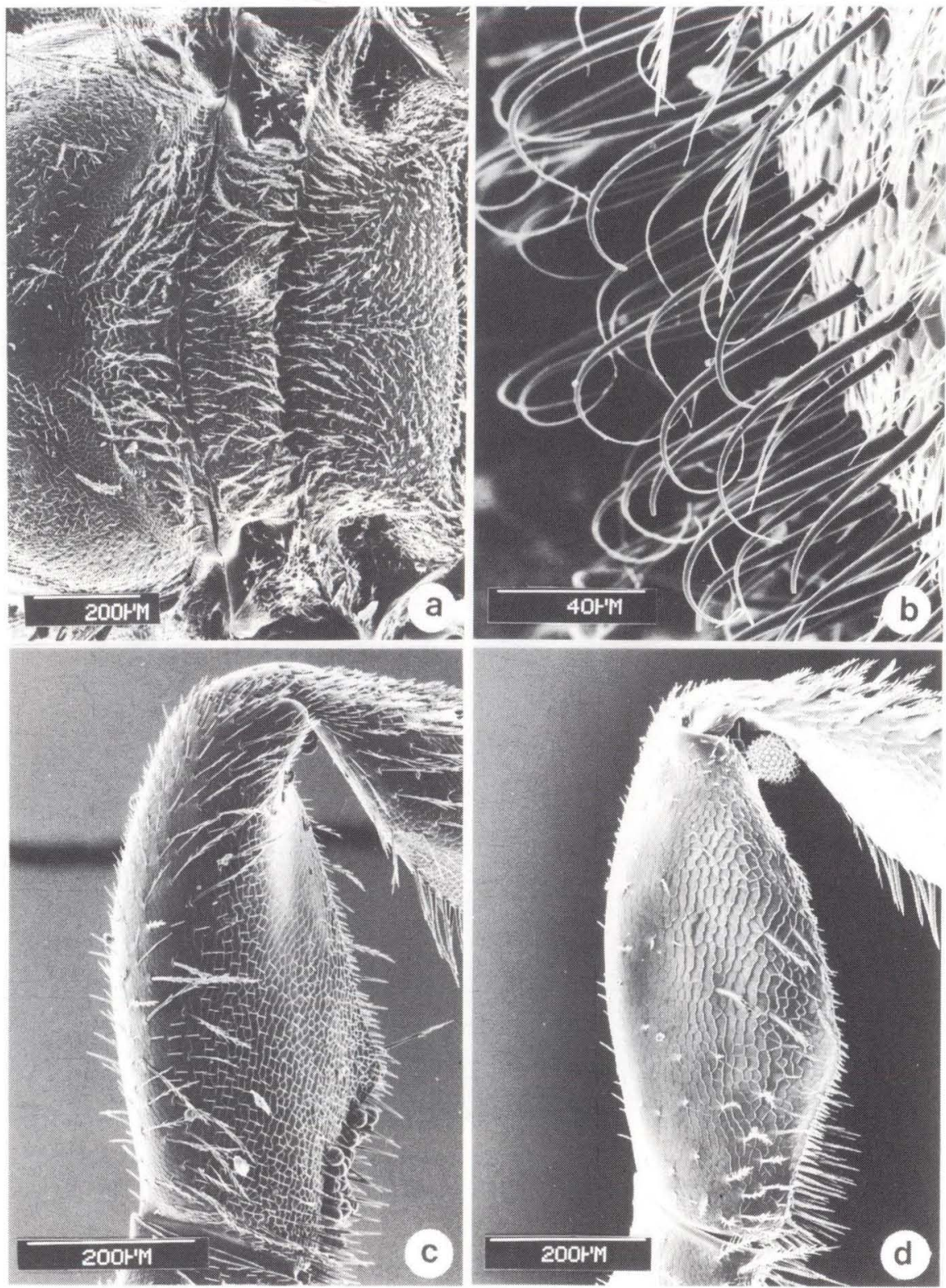

Fig. 4. (a) Panurgillus pereziae, escutelo, metanoto e propódeo; (b) P. minutus, pêlos em gancho no lado ventral do mesosoma; (c) P. pereziae, fêmur médio; (d) P. vagabundus, fêmur médio. 

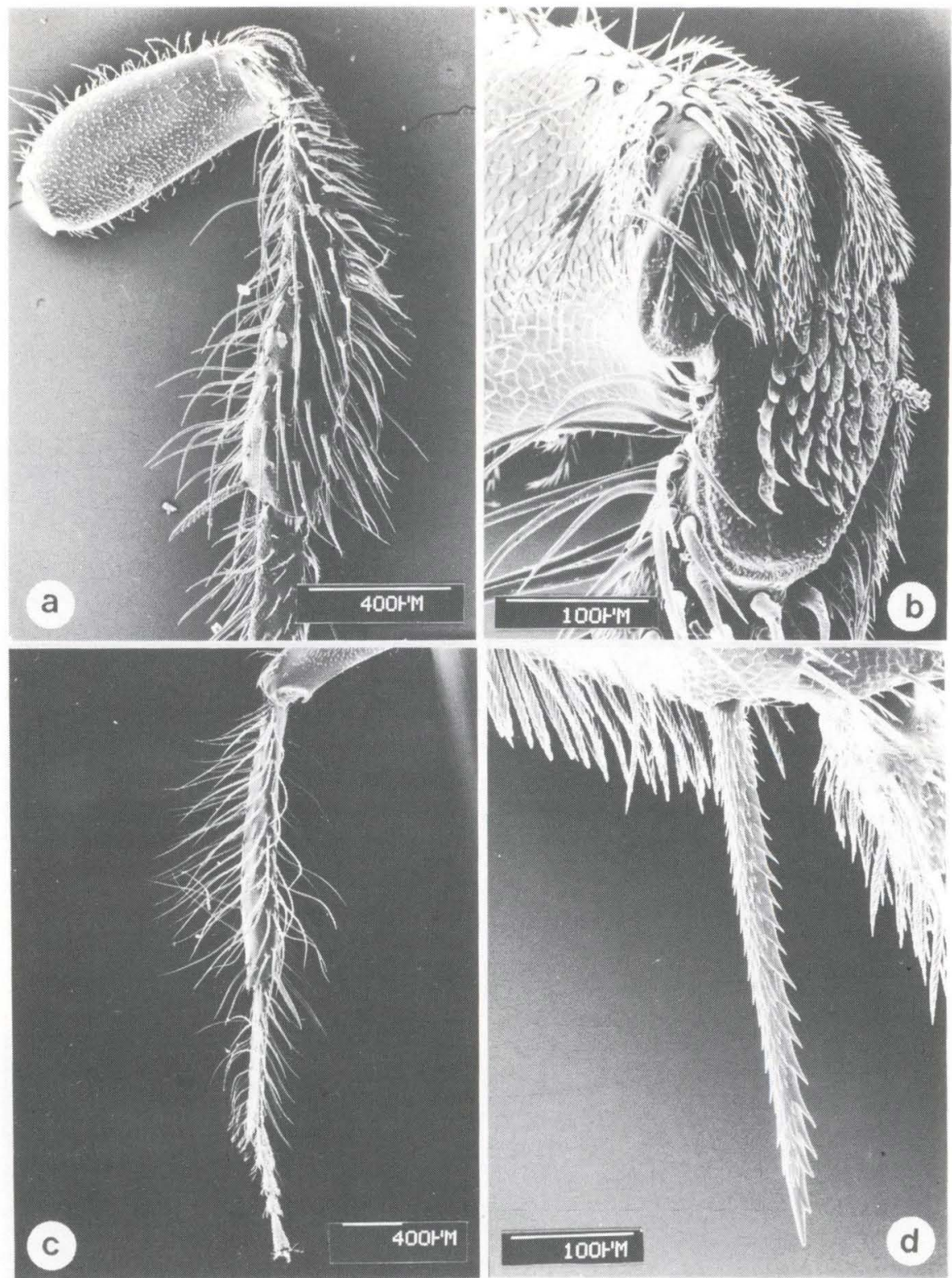

Fig. 5. (a) Panurgillus vagabundus, perna posterior esquerda com fêmur, tíbia e esporăo; (b) placa basitibial; (c) P. flavitarsis, perna posterior direita, tíbia e tarsos; (d) P. malvacearum, esporão da perna média.

Holótipo fêmea. Brasil, Rio Grande do Sul: Capão da Canoa (Arroio Teixeira), 05-XII-1992, I. Alves dos Santos leg.; alótipo, macho, com os mesmos dados do holótipo. Parátipo com os mesmos dados do holótipo, 1 fêmea (DZUP); parátipos com os mesmos dados do holótipo, 2 fềmeas (LPB); parátipo com os 
mesmos dados do holótipo, 1 fêmea (FZB); parátipos com os mesmos dados do holótipo, 2 fêmeas (MZUSP); parátipos com os mesmos dados do holótipo, duas fêmeas (UFPB); parátipos com os mesmos dados do holótipo, duas fêmeas (LSEA).

Flores visitadas. Eryngium nudicaule Lam. (Apiaceae).

Sazonalidade. Dezembro

Distribuição geográfica. BRASIL, Rio Grande do Sul, Litoral.

Etimologia. minutus $($ latim $)=$ pequeno. $\mathrm{O}$ nome destaca o pequeno tamanho destas abelhas.

\section{Panurgillus flavitarsis sp.n.}

Figs 2c, 3a, 5c

Diagnose. Tíbias anteriores com uma mancha amarela na base, as médias sem mancha; tarsos de todas as pernas amarelos; pontuação no mesoscuto muito esparsa; cabeça larga, os olhos paralelos; fóvea facial alargada; placa labral larga, levemente emarginada; fêmur médio em curva contínua, sem ângulo no lado ventral; basitarso médio estreito; pilosidade comprida na face e no mesoscuto; escopa com pêlos muito compridos; 10-12 hâmulos. No macho a placa labral fortemente emarginada; tíbia anterior com estria amarela, tíbia média com uma pequena mancha amarela na base.

Holótipo fêmea. Comprimento total aproximado $7,3 \mathrm{~mm}$; asa anterior 5,4 $\mathrm{mm}$; largura da cabeça $2,32 \mathrm{~mm}$; comprimento da cabeça $1,7 \mathrm{~mm}$; largura do metasoma 2,24 mm.

Tegumento preto; os últimos flagelômeros amarelo-pálidos por baixo; tégula ocre, translúcida; asas subhialinas com as veias amareladas, uma mancha amarela parda ao longo da $\mathrm{C}+\mathrm{Sc}$, pterostigma pardo-castanho; tarsos dos três pares de pernas amarelos; uma mancha amarela pequena na base das tíbias anteriores, sem mancha nas tíbias médias; depressões marginais dos tergos pouco destacadas, translúcidas na margem posterior.

Pilosidade toda amarelada nas pernas; esbranquiçada na cabeça e no mesosoma; longa no vértice (até $0,4 \mathrm{~mm}$ ), pronoto, mesoscuto, escutelo, metanoto e nos mesepisternos (cerca de $0,3 \mathrm{~mm}$ ); pêlos plumosos mais curtos, relativamente densos nos lóbulos pronotais; pêlos retos, sem gancho na face ventral do mesepisterno; escopa inteiramente pálida com cerdas não plumosas, muito longas (até $0,74 \mathrm{~mm}$ ), esparsas (Fig. 5c); nos flancos do propódeo comprida como nos mesepisternos; comprimento dos pêlos em T5 $0,5 \mathrm{~mm}$, franjas apicais de pêlos amarelados; pêlos no escapo até $0,3 \mathrm{~mm}$.

Pontuação muito densa e grossa na fronte, $\varnothing$ dos pontos cerca de $0,04 \mathrm{~mm}$, os intervalos reticulados, $<1 / 2 \mathrm{dp}$; um pouco mais grossa na metade inferior da face, especialmente no clípeo e na área supraclipeal perto do clípeo, os intervalos lisos; na área supraclipeal mais esparsa (1-2dp); nas paroculares mais densa (cerca de $1 / 2 \mathrm{dp}$ ), na área ocelorbital muito esparsa, nas genas fina, desaparecendo para baixo, os intervalos lisos; no mesoscuto e escutelo fina $(\varnothing$ cerca de $0,02 \mathrm{~mm}$ ), muito esparsa, os intervalos micro-reticulados, até $5 \mathrm{dp}$; o mesoscuto deprimido ao longo 
do sulco médio; no metanoto mais densa (cerca de 1dp); nos mesepisternos fina, esparsa (até $3 \mathrm{dp}$ ), adensada para cima, os intervalos fortemente reticulados; nos metepisternos com retículo forte; mais evidente atrás nos flancos e na face posterior do propódeo, os intervalos com retículo forte, nos cantos posteriores muito fina, passando a reticulada junto à área basal; nos tergos relativamente densa, tornando-se esparsa em direção às depressões marginais, os intervalos lisos até fracamente micro-reticulados; distância entre os pontos em T1 até $2 \mathrm{dp}$, em T2 e seguintes mais densa (1-2dp); em T5 mais grossa e esparsa; as depressões marginais dos tergos micro-reticuladas.

Comprimento do olho $1,10 \mathrm{~mm}$, largura $0,60 \mathrm{~mm}$; olhos paralelos, distâncias interorbitais: superior $1,52 \mathrm{~mm}$, média $1,5 \mathrm{~mm}$, inferior $1,56 \mathrm{~mm}$; distância interalveolar $0,40 \mathrm{~mm}$; alveolorbital $0,38 \mathrm{~mm}$; alveolocelar $0,52 \mathrm{~mm}$; $\varnothing$ alvéolo $0,16 \mathrm{~mm}$; interocelar $0,33 \mathrm{~mm}$; ocelorbital $0,45 \mathrm{~mm}$; $\varnothing$ ocelo médio $0,18 \mathrm{~mm}$; comprimento das suturas subantenais: a externa $0,4 \mathrm{~mm}$, a interna $0,32 \mathrm{~mm}$, largura da área subantenal $0,17 \mathrm{~mm}$; comprimento do clípeo $0,5 \mathrm{~mm}$, largura $1,6 \mathrm{~mm}$; clipeocelar $0,8 \mathrm{~mm}$; linha frontal em forma de sulco chegando até o ocelo médio; fóvea facial muito grande, levemente reticulada, opaca, com alguns pontos finos e duas depressões semicirculares, podendo faltar, a maior largura na metade superior, comprimento $0,5 \mathrm{~mm}$, largura $0,22 \mathrm{~mm}$; largura do labro $0,76 \mathrm{~mm}$, placa labral lisa, sem rúgulas, os lados um pouco convergentes para o ápice, este levemente emarginado (Fig. 3a), comprimento $0,3 \mathrm{~mm}$, largura $0,42 \mathrm{~mm}$; escapo: comprimento e $\varnothing$ máximo $0,52 \mathrm{~mm}, 0,16 \mathrm{~mm}$; flagelo clavado, comprimento dos três primeiros flagelômeros $0,19 \mathrm{~mm}, 0,13 \mathrm{~mm}, 0,13 \mathrm{~mm}, \varnothing$ do terceiro $0,15 \mathrm{~mm}$, $\varnothing$ máximo 0,19 ; flagelo e pedicelo juntos $1,62 \mathrm{~mm} ; 10$ a 12 hâmulos; fêmur médio em curva contínua, sem ângulo; basitarso médio 3-4 vezes mais longo que largo $(0,72: 0,2$ $\mathrm{mm}$ ); área basal do propódeo triangular, subacuminada, com rugas longitudinais paralelas passando a irregulares até transversais no canto posterior do propódeo, a carena média mais forte que as laterais, alcançando a margem posterior do propódeo; fóveas laterais de T2 grande, com os bordos indefinidos, superfície micropontuada, comprimento $0,5 \mathrm{~mm}$, largura $0,24 \mathrm{~mm}$; placa pigidial rebordada, com estrias transversais muito evidentes, carena média fraca, grossa e baixa.

Alótipo, macho. Comprimento total aproximado $6,6 \mathrm{~mm}$; asa anterior 5,0 $\mathrm{mm}$; largura da cabeça 2,24 mm; comprimento da cabeça $1,64 \mathrm{~mm}$; largura do metasoma $1,84 \mathrm{~mm}$.

Tegumento preto com o flagelo amarelo por baixo; metade posterior da tégula pardo-escura, translúcida, metade anterior preta; asas subhialinas, com as veias pardo-méleas, pterostigma amarelo no meio, as margens escuras, $\mathrm{C}+\mathrm{Sc}$ inteiramente amarela; os tarsos dos três pares de pernas amarelos; face anterior da tíbia anterior com estria amarela; uma mancha amarela pequena na base das tíbias médias; depressões marginais dos tergos pretas.

Pilosidade amarelada nas pernas, esbranquiçada no mesosoma e cabeça, como na fêmea; em T6 os pêlos $0,4-0,5 \mathrm{~mm}$; depressões marginais com alguns pêlos curtos, deitados para trás; pêlos densos adpressos em E2-E5; no escapo 0,28 mm.

Pontuação muito densa em toda a face, distância $<1 / 2 \mathrm{dp}$, mesmo no clípeo, $\varnothing$ cerca de $0,03 \mathrm{~mm}$, no clípeo e áreas paroculares um pouco mais grossa, os intervalos reticulados com alguns micropontos intercalados; nas genas um pouco 
mais esparsa, os intervalos lisos, cerca de $1 \mathrm{dp}$, no vértice como nas genas, mas com os intervalos reticulados, a área ocelorbital sem pontos junto aos ocelos, porém com retículo forte; no mesoscuto e escutelo esparsa $(\varnothing$ cerca de $0,03 \mathrm{~mm}, 2-3 \mathrm{dp})$, os intervalos fracamente micro-reticulados, nos lados do mesoscuto mais densa; no metanoto mais densa e mais grossa, os intervalos reticulados; nos mesepisternos densa ( $1 \mathrm{dp}, \varnothing 0,3-0,4 \mathrm{~mm}$ ), os intervalos fortemente reticulados; metepisternos micropontuados; grossa e muito densa para trás nos flancos do propódeo, na área basal os intervalos formando rúgulas, os cantos posteriores micro-reticulados, densa na face posterior, os intervalos fortemente micro-reticulados; nos tergos densa, em $\mathrm{T} 1$ um pouco menor que $1 \mathrm{dp}$, em T2 e seguintes um pouco mais densa e fina como em T1; em T6 mais grossa; depressões marginais dos tergos micro-reticuladas, com alguns pontos.

Comprimento do olho $1,15 \mathrm{~mm}$, largura $0,64 \mathrm{~mm}$; olhos subparalelos, distâncias interorbitais: superior $1,46 \mathrm{~mm}$, média $1,47 \mathrm{~mm}$, inferior $1,48 \mathrm{~mm}$; interalveolar $0,36 \mathrm{~mm}$; alveolorbital $0,38 \mathrm{~mm}$; alveolocelar $0,52 \mathrm{~mm} ; \varnothing$ alvéolo $0,16 \mathrm{~mm}$; interocelar $0,38 \mathrm{~mm}$; ocelorbital $0,46 \mathrm{~mm}$; $\varnothing$ ocelo médio $0,16 \mathrm{~mm}$; comprimento das suturas subantenais: a externa $0,38 \mathrm{~mm}$, a interna $0,26 \mathrm{~mm}$ e largura da área subantenal $0,15 \mathrm{~mm}$; comprimento do clípeo $0,46 \mathrm{~mm}$, largura 1,5 $\mathrm{mm}$; clipeocelar $0,75 \mathrm{~mm}$; linha frontal como na fêmea; fóvea facial mais lisa e estreita que na fêmea, sem depressões redondas, afastada da órbita para cima, comprimento $0,4 \mathrm{~mm}$ largura $0,1 \mathrm{~mm}$; largura do labro $0,72 \mathrm{~mm}$, placa labral lisa, relativamente curta com ápice profundamente emarginado formando dois dentes triangulares, fracas rúgulas transversais, comprimento $0,2 \mathrm{~mm}$, largura $0,34 \mathrm{~mm}$; escapo: comprimento e $\varnothing$ máximo $0,44 \mathrm{~mm}, 0,14 \mathrm{~mm}$; flagelo ligeiramente clavado, comprimento dos três primeiros flagelômeros $0,19 \mathrm{~mm}, 0,1 \mathrm{~mm}$, juntos $1,7 \mathrm{~mm} ; 9$ hâmulos; basitarso médio quatro vezes mais longo que largo 0,58:0,14) Área basal do propóedo semilunar, subacuminada, a carena média mais forte que as laterais alcançando e ultrapassando a margem posterior do propódeo como carena fina, as rúgulaas laterais irregulares até transversais no canto posterior; T2 sem fóveas laterais; E6 profundamente emarginado no meio.

Holótipo fêmea. Brasil, Rio Grande do Sul: São Francisco de Paula (Pró-Mata), 9-I-1996, Birgit Harter leg.; alótipo, macho, com os mesmos dados do holótipo (DZUP). Parátipos os mesmos dados do holótipo, uma fêmea; Cambará do Sul, 6-II-1993, I. Alves dos Santos leg., 1 macho; da mesma localidade e coletor, 25-II-1994, 1 macho; 15-III-1992, 1 macho, (LPB); parátipos de Bom Jesus, 11-IV-1984, M. Hoffmann leg., duas fêmeas; da mesma localidade, 11-IV-1984, D. Wittmann leg., duas fêmeas; Canela, 22-I-1984, D. Wittmann leg, 1 fêmea, Canguçu, 8-XII-1986, R. Radtke leg., 1 fêmea (FZB); parátipos com os mesmos dados do holótipo, uma fêmea; Osório (RS 486) 26-II-1994, I. Alves dos Santos leg., 1 macho (MZUSP); parátipos com os mesmos dados do holótipo, 1 fêmea; Cambará do Sul, 15-III-1992, I. Alves dos Santos leg., 1 macho (UFPB); parátipo de Osório (RS 486) 26-II-1994, I. Alves dos Santos leg., 1 fêmea (LSEA).

Flores visitadas. Ludwigia peruviana (L.) Hara, L. longifolia (DC.) Hara (Onagraceae).

Sazonalidade. Dezembro até abril. 
Distribuição geográfica. BRASIL: Rio Grande do Sul, Litoral, Serra Geral, Serra do Sudeste.

Etimologia. O nome refere-se a cor amarela dos tarsos.

\section{Panurgillus formosus sp.n.}

Diagnose. Fêmea com os lóbulos pronotais amarelos; as mandíbulas amareladas, tíbias anteriores e médias com uma mancha amarela na base; pontuação muito fina e densa na parte superior da face, no mesoscuto e no T2-T4; olhos levemente convergentes para baixo; placa labral tão longa quanto larga; mesoscuto com pêlos muito curtos; pêlos em gancho no lado ventral dos mesepisternos; fêmur médio com dente na face ventral. Macho com a placa labral retangular e amarela; clípeo, áreas paroculares inferiores, área supraclipeal e cantos inferiores das genas amarelos; metasoma amarelado, as fóveas laterais de $\mathrm{T} 2$ pequenas e pretas.

Holótipo fêmea. Comprimento total aproximado $4,8 \mathrm{~mm}$; asa anterior 3,0 $\mathrm{mm}$; largura da cabeça $1,54 \mathrm{~mm}$; comprimento da cabeça $1,16 \mathrm{~mm}$; largura do metasoma $1,48 \mathrm{~mm}$.

Tegumento preto com a placa labral castanho-escura; mandíbulas amarelas, somente o terço apical preto; o flagelo amarelo por baixo; lóbulos pronotais amarelos; tégula translúcida; asas subhialinas, com veias e pterostigma castanhos; extremidade apical dos fêmures anteriores e médios com uma pequena mancha amarela; uma estria amarela na base da tíbia anterior, uma mancha amarela na base das tíbias médias; tarsos de todos os pares ocres até castanho-escuros; depressões marginais dos tergos fracamente translúcidas.

Pilosidade esbranquiçada, rala e curta na face, no vértice e nas genas cerca de $0,1 \mathrm{~mm}$; muito curta e inconspícua no mesoscuto (cerca de $0,04 \mathrm{~mm}$ ), um pouco mais comprida no escutelo e metanoto; um pouco mais evidente e plumosa nos mesepisternos (até 0,2 $\mathrm{mm}$ ), ventralmente com pêlos em gancho; escopa inteiramente branca com cerdas pouco plumosas, pouco numerosas, relativamente curtas (cerca de 0,28 mm); em T5 pêlos amarelos, $0,26 \mathrm{~mm}$ e curta franja apical escura; pêlos no escapo até $0,06 \mathrm{~mm}$.

Pontuação na fronte, áreas supraclipeal e subantenal, vértice e área ocelorbital muito fina e densa $(\leq 0,02 \mathrm{~mm}<1 \mathrm{dp})$, os intervalos reticulados; um pouco mais grossa e mais esparsa (até $2 \mathrm{dp}$ ) no clípeo e nas áreas paroculares, os intervalos reticulados, com alguns micropontos intercalados; no mesoscuto muito fina e densa $(\leq 0,02 \mathrm{~mm},<1 \mathrm{dp})$, os intervalos reticulados; no escutelo e metanoto mais grossa e um pouco mais densa que no mesoscuto; nos mesepisternos relativamente grossa, os intervalos fortemente reticulados; nos flancos do propódeo com micropontuação, nos cantos posteriores muito densa, e inconspícua devido ao forte retículo entre os pontos; em T2-T4 muito fina e densa $(\varnothing<0,02 \mathrm{~mm}$; $\leq 1 \mathrm{dp})$, ficando um pouco mais esparsa em direção à depressão marginal, em T1 um pouco mais grossa, em T5 muito fina e densa na parte anterior, mais grossa e esparsa na parte posterior; depressões marginais distintamente micropontuadas.

Comprimento do olho $0,86 \mathrm{~mm}$, largura $0,52 \mathrm{~mm}$; olhos convergentes para baixo, distâncias interorbitais: superior $1,06 \mathrm{~mm}$, média $0,94 \mathrm{~mm}$, inferior $0,9 \mathrm{~mm}$; 
distância interalveolar $0,24 \mathrm{~mm}$; alveolorbital $0,22 \mathrm{~mm}$; alveolocelar $0,4 \mathrm{~mm}$; $\varnothing$ alvéolo $0,12 \mathrm{~mm}$; interocelar $0,22 \mathrm{~mm}$; ocelorbital $0,32 \mathrm{~mm}$; $\varnothing$ ocelo médio 0,12 $\mathrm{mm}$; comprimento das suturas subantenais: a externa $0,3 \mathrm{~mm}$, a interna $0,26 \mathrm{~mm}$, largura da área subantenal $0,1 \mathrm{~mm}$; comprimento do clípeo $0,36 \mathrm{~mm}$, largura 0,8 $\mathrm{mm}$; clípeocelar $0,64 \mathrm{~mm}$; linha frontal pouco evidente; fóvea facial estreita e longa, bem marcada, com alguns pontos piligeros, distanciando-se da órbita para cima; comprimento $0,26 \mathrm{~mm}$, largura $0,06 \mathrm{~mm}$; largura do labro $0,4 \mathrm{~mm}$, placa labral pequena, lisa, sem rúgulas, os lados levemente convergentes, a margem anterior em arco rebaixado, tão longa como larga (comprimento $0,24 \mathrm{~mm}$, largura $0,24 \mathrm{~mm}$ ); escapo: comprimento e $\varnothing$ máximo $0,36 \mathrm{~mm}, 0,12 \mathrm{~mm}$; flagelo ligeiramente clavado, comprimento dos três primeiros flagelômeros $0,12 \mathrm{~mm}, 0,08 \mathrm{~mm}, 0,08 \mathrm{~mm}, \varnothing$ do terceiro $0,12 \mathrm{~mm}, \varnothing$ máximo $0,14 \mathrm{~mm}$; flagelo e pedicelo juntos $1,06 \mathrm{~mm} ; 6$ a 7 hâmulos; fêmur médio com ângulo bem marcado, agudo, com ponta fina; basitarso médio mais que duas vezes mais longo que largo $(0,38: 0,16 \mathrm{~mm})$; área basal do propódeo semilunar com rugas fortes subparalelas até vermiculadas, a média alcançando o bordo posterior do propódeo; T2 com fóveas laterais bem marcadas, comprimento $0,20 \mathrm{~mm}$, largura $0,12 \mathrm{~mm}$; placa pigidial rebordada, com carena média rebaixada, a superfície fortemente reticulada.

Alótipo macho. Comprimento total aproximado 4,0 mm; asa anterior 2,68 $\mathrm{mm}$; largura da cabeça $1,28 \mathrm{~mm}$; comprimento da cabeça $1,26 \mathrm{~mm}$; largura do metasoma $1,14 \mathrm{~mm}$.

Tegumento predominantemente preto na cabeça e no mesosoma; clípeo amarelo com uma pequena mancha preta a cada lado junto à fóvea tentorial anterior, a margem anterior translúcida; áreas paroculares inferiores e supraclipeal amarelas até a tangente inferior dos alvéolos antenais; cantos inferiores das genas amarelos; labro amarelo; metade basal das mandíbulas amarela; antena amarela por baixo (inclusive o escapo) exceto os últimos flagelômeros; metade basal da tégula amarela, metade apical translúcida; lóbulos pronotais amarelos; asas subhialinas com veias e pterostigma castanho-claros, a base $\mathrm{da} \mathrm{C}+\mathrm{Sc}$ amarela; pernas anteriores amarelas; coxa, trocânter e fêmur das pernas médias e posteriores castanho-claros, exceto a extremidade apical do fêmur, amarela; tíbias média e posterior predominantemente amarelas, a parte apical com uma faixa castanha; tarsos amarelos.

Pilosidade esbranquiçada, esparsa e curta; na cabeça até $0,06 \mathrm{~mm}$; no mesoscuto cerca de $0,04 \mathrm{~mm}$; os pêlos mais plumosos e densos no metanoto e no propódeo, no escapo até $0,06 \mathrm{~mm}$.

Pontuação muito fina e uniformemente densa na metade superior da cabeça $(<1 / 2 \mathrm{dp}, \varnothing 0,02 \mathrm{~mm})$, nas genas um pouco mais grossa e esparsa, na metade inferior da cabeça mais grossa e esparsa, os intervalos reticulados; no mesoscuto muito fina e densa ( $\leq 1 \mathrm{dp} ; \varnothing<0,02 \mathrm{~mm}$ ), os intervalos levemente reticulados; no escutelo e metanoto mais grossa e mais densa; nos mesepisternos grossa, os intervalos fortemente reticulados; na face posterior e nos cantos laterais do propódeo densa, os intervalos retículados; nos tergos fina e densa $(<1 \mathrm{dp})$.

Comprimento do olho $0,92 \mathrm{~mm}$, largura $0,5 \mathrm{~mm}$; olhos convergentes para baixo, distâncias interorbitais: superior $1,0 \mathrm{~mm}$, média $0,88 \mathrm{~mm}$, inferior $0,86 \mathrm{~mm}$; distância interalveolar $0,24 \mathrm{~mm}$; alveolorbital $0,22 \mathrm{~mm}$; alveolocelar $0,38 \mathrm{~mm}$; $\varnothing$ 
alvéolo $0,12 \mathrm{~mm}$; interocelar $0,2 \mathrm{~mm}$; ocelorbital $0,28 \mathrm{~mm}$; $\varnothing$ ocelo médio 0,12 mm; suturas subantenais: a externa $0,28 \mathrm{~mm}$, a interna $0,24 \mathrm{~mm}$, largura da área subantenal 0,08 $\mathrm{mm}$; comprimento do clípeo $0,4 \mathrm{~mm}$, largura $0,82 \mathrm{~mm}$; clipeocelar $0,58 \mathrm{~mm}$; linha frontal pouco evidente; fóvea facial pequena, bem marcada, comprimento $0,12 \mathrm{~mm}$, largura $0,06 \mathrm{~mm}$; largura do labro $0,36 \mathrm{~mm}$, placa labral subretangular, lisa, margem lateral pouco evidente, comprimento $0,16 \mathrm{~mm}$, largura $0,22 \mathrm{~mm}$; comprimento e $\varnothing$ máximo do escapo $0,3 \mathrm{~mm}, 0,12 \mathrm{~mm}$; comprimento dos três primeiros flagelômeros $0,12 \mathrm{~mm}, 0,08 \mathrm{~mm}, 0,09 \mathrm{~mm}, \varnothing$ do terceiro 0,13 mm, maior $\varnothing 0,16 \mathrm{~mm}$; flagelo e pedicelo juntos 1,3 gmm; 6 hâmulos; comprimento do basitarso médio $0,38 \mathrm{~mm}$, largura, $0,08 \mathrm{~mm}$; área basal do propódeo pouco evidente, com curtas carenas subparalelas até vermiculadas; T2 com fóveas laterais pretas, pequenas, ovais e evidentes, comprimento $0,08 \mathrm{~mm}$, largura 0,05 $\mathrm{mm}$.

Holótipo fêmea. BRAsil, Rio Grande do Sul: Quaraí (Fazenda Pai Passo), 13-XII-1989, C. Schlindwein leg.; alótipo macho, com os mesmos dados do holótipo (DZUP). Parátipos com os mesmos dados do holótipo, duas fêmeas (LPB); parátipo de Quaraí (Passo da Guarda), 23-XI-1985, M. Hoffmann leg., 1 fêmea (FZB); parátipos com os mesmos dados do holótipo, uma fêmea (MZUSP); parátipos com os mesmos dados do holótipo, duas fêmeas (UFPB); parátipo com os mesmos dados do holótipo, 1 fêmea (LSEA).

Flores visitadas. Eryngium nudicaule Lam. (Apiaceae).

Sazonalidade. Novembro, dezembro.

Distribuição geográfica. BRASIL: Rio Grande do Sul, Campanha.

Etimologia. O nome refere-se aos desenhos amarelos do macho, sendo mais ricos que nas outras espécies deste gênero.

Comentário. Visitam as mesmas flores que $P$. minutus. Ainda não foram encontradas simpatricamente. As fêmeas das duas espécies são muito semelhantes. Em $P$. formosus a pontuação é mais fina e uniformemente densa na metade superior da face, enquanto que é muito esparsa especialmente na área ocelorbital de $P$. minutus. A pontuação é mais fina e densa nas fêmeas de $P$. formosus, no vértice, no mesoscuto e nos tergos. Os machos de $P$. minutus são facilmente reconhecidos pela placa labral triangular e preta, subquadrangular e amarela nos machos de $P$. formosus.

\section{Panurgillus guariticola sp.n.}

Diagnose. Tegumento em geral liso e brilhante, também no mesoscuto; tíbias anteriores e médias com mancha amarela na base; olhos convergentes embaixo; pilosidade curta no mesoscuto; pêlos em gancho na face ventral do mesepisterno; fóvea facial muito comprida e estreita; placa labral quase tão longa quanto larga.

Holótipo fêmea. Comprimento total aproximado $5,3 \mathrm{~mm}$; asa anterior 4,2 $\mathrm{mm}$; largura da cabeça $1,72 \mathrm{~mm}$; comprimento da cabeça $1,48 \mathrm{~mm}$; largura do metasoma $1,85 \mathrm{~mm}$.

Tegumento preto com o flagelo amarelo por baixo; as mandíbulas castanhoescuras até pretas, tégula amarelada, translúcida; asas moderadamente fuscas com 
veias e pterostigma pardo-méleos, $\mathrm{C}+\mathrm{Sc}$ amarelo até o pterostigma; mancha amarela pequena na base das tíbias anteriores e médias; pernas castanho-escuras, tarsos ocres; depressões marginais dos tergos translúcidas, desbotadas.

Pilosidade esbranquiçada, rala; comprimento dos pêlos no vértice $0,16 \mathrm{~mm}$; muito curta no mesoscuto $(0,06 \mathrm{~mm})$, no escutelo alguns pêlos compridos; pilosidade mais comprida no metanoto e nos mesepisternos, estes inferiormente com pêlos finos em gancho; escopa inteiramente pálida com cerdas não plumosas, comprimento $0,4 \mathrm{~mm}$; no T5 $0,35 \mathrm{~mm}$, com franjas apical curta escura; pêlos no escapo até 0,1 $\mathrm{mm}$.

Pontuação na fronte fina e densa (cerca de $0,02 \mathrm{~mm}, \leq 1 \mathrm{dp}$ ); os intervalos lisos em toda a cabeça; na metade inferior da face mais esparsa (cerca de 2-3dp) e mais grossa (até $0,06 \mathrm{~mm}$ no clípeo), com alguns micropontos intercalados; fina nas genas (1dp); no mesoscuto muito fina e fraca, mais fina que na fronte $(<0,02 \mathrm{~mm})$, os intervalos ligeiramente maiores que os pontos, lisos; no escutelo e metanoto mais grossa e mais esparsa que no mesoscuto; nos mesepisternos esparsa (até $3 \mathrm{dp}$ ), adensando-se para cima, intervalos reticulados; nos metepisternos com retículo muito evidente; os cantos posteriores do propódeo quase sem pontos e com retículo fraco, na face posterior adensando-se para baixo, nos flancos densa e fina passando inferiormente a rugulosa; bastante esparsa no T1, com intervalos lisos, no T2 e seguintes adensada para a base e muito esparsa para a depressão, no T5 mais grossa, esparsa, com retículo fraco; nas depressões marginais dos tergos com micro-retículo fraco, quase lisa.

Comprimento do olho $0,96 \mathrm{~mm}$, largura $0,46 \mathrm{~mm}$; distâncias interorbitais: superior $1,26 \mathrm{~mm}$, média $1,26 \mathrm{~mm}$, inferior $1,1 \mathrm{~mm}$; distância interalveolar 0,26 $\mathrm{mm}$; alveolorbital $0,34 \mathrm{~mm}$; alveolocelar $0,45 \mathrm{~mm}$; $\varnothing$ alvéolo $0,13 \mathrm{~mm}$; interocelar $0,27 \mathrm{~mm}$; ocelorbital $0,43 \mathrm{~mm}$; $\varnothing$ ocelo médio $0,14 \mathrm{~mm}$; comprimento das suturas subantenais: a externa $0,33 \mathrm{~mm}$, a interna $0,28 \mathrm{~mm}$, largura da área subantenal 0,12 $\mathrm{mm}$; clípeo ligeiramente mais curto que a metade da sua largura (comprimento 0,44 $\mathrm{mm}$, largura $1,0 \mathrm{~mm}$ ); clipeocelar $0,64 \mathrm{~mm}$; linha frontal em forma de sulco até o ocelo médio; fóvea facial longa e estreita, lisa, comprimento $0,4 \mathrm{~mm}$, largura 0,07 $\mathrm{mm}$, sem pêlos, o bordo externo mais elevado; largura do labro $0,5 \mathrm{~mm}$, placa labral lisa, ápice em arco rebaixado, os lados convergentes, comprimento $0,22 \mathrm{~mm}$, largura $0,32 \mathrm{~mm}$; escapo: comprimento e $\varnothing$ máximo $0,42 \mathrm{~mm}, 0,1 \mathrm{~mm}$; flagelo ligeiramente clavado, comprimento dos três primeiros flagelômeros $0,12 \mathrm{~mm}, 0,1 \mathrm{~mm}, 0,1 \mathrm{~mm}$, $\varnothing$ do terceiro $0,14 \mathrm{~mm}$; maior $\varnothing 0,16 \mathrm{~mm}$; flagelo e pedicelo juntos $1,5 \mathrm{~mm} ; 8$ a 9 hâmulos; fêmur médio com ângulo acentuado; basitarso médio duas vezes mais longo que largo $(0,46: 0,22 \mathrm{~mm})$; área basal do propódeo semilunar, porém não bem definida, com algumas carenas curtas, relativamente fortes, subparalelas, não alcançando o canto posterior do propódeo; T2 com fóveas laterais pouco evidentes, rasas, comprimento $0,36 \mathrm{~mm}$, largura $0,15 \mathrm{~mm}$; placa pigidial rebordada, com a carena média grossa, baixa, sem rúgulas transversais.

Macho não conhecido.

Holótipo fêmea. Brasil, Rio Grande do Sul: Lavras do Sul (Rincão do Inferno), 18-XI-1992, C. Schlindwein leg. Parátipos: Caçapava do Sul (Minas de Camaquã), 27-X-1990, B. Hiller leg., 1 fềmea (DZUP); parátipo de Caçapava do 
Sul (Minas de Camaquã), 27-X-1990, B. Hiller leg., três fêmeas; Caçapava do Sul (Guaritas), 21-X-1994, C. Schlindwein leg., 1 fêmea (LPB); parátipo da mesma localidade e coletor do holótipo, 16-XI-1992, 1 fêmea (MZUSP); parátipos de Caçapava do Sul (Guaritas), 9-XI-1991, C. Schlindwein leg., 1 fêmea (FZB); parátipos com os mesmos dados do holótipo, 1 fềmea; Caçapava do Sul (Guaritas), 9-XI-1991, C. Schlindwein leg., 1 fêmea (UFPB); parátipo da mesma localidade e coletor do holótipo, 16-XI-1992, 1 fêmea (LSEA).

Flores visitadas. Eryngium nudicaule Lam. (Apiaceae), Hypochoeris petiolaris (Hook. et Arn.) Griseb., Hysterionica filiformis (Spreng.) Cabrera (Asteraceae), Notocactus sellowii (Link \& Otto) Theun., Opuntia brunneogemmia (Ritter) Schlindwein (Cactaceae), Scoparia dulcis L., S. montevidensis (Spreng.) Fries (Scrophulariaceae), Nierembergia calycina Hooker (Solanaceae).

Sazonalidade. Outubro, novembro.

Distribuição geográfica. BRASIL: Rio Grande do Sul, Serra do Sudeste.

Etimologia. O nome é alusivo a região das "Guaritas", onde foram coletadas estas abelhas. Guaritas são morros-testemunho, de conglomerado câmbrio-ordoviciano na Serra do Sudeste no Rio Grande do Sul.

\section{Panurgillus hamatus sp.n.}

Figs $2 \mathrm{e}, 3 \mathrm{~b}$

Diagnose. Fêmea com clípeo e placa labral estreitos; olhos convergentes em baixo; pontuação muito densa no mesoscuto, os intervalos fortemente reticulados; pêlos muito curtos no mesoscuto; tíbias anteriores e médias com mancha amarela na base; pêlos em gancho na face ventral do mesepisterno; 7 hâmulos. Macho. Clípeo com mancha amarela no meio; mandíbulas amarelas com exceção de uma mancha preta na base; lóbulos pronotais com uma mancha amarela; tíbias anteriores largamente amarelas, médias com uma estria amarela, posteriores com a metade basal amarela; fêmures com uma mancha amarela na extremidade apical.

Holótipo fêmea. Comprimento total aproximado $5,0 \mathrm{~mm}$; asa anterior 3,85 $\mathrm{mm}$; largura da cabeça $1,64 \mathrm{~mm}$; comprimento da cabeça $1,36 \mathrm{~mm}$; largura do metasoma $1,7 \mathrm{~mm}$.

Tegumento preto com o flagelo amarelo por baixo; tégula ocre, translúcida; asas fuscas com as veias e pterostigma pardo-méleos; uma mancha amarela na base da $\mathrm{C}+\mathrm{Sc}$ um pouco prolongada; manchas amarelas pequenas na base das tíbias anteriores e médias; depressões marginais dos tergos translúcidas.

Pilosidade esbranquiçada, esparsa e rala; na face, no vértice e nas genas 0,12 $\mathrm{mm}$, no mesoscuto extremamente fina e curta (cerca de $0,04 \mathrm{~mm}$ ); no pronoto e nos lóbulos com pêlos curtos, densos e plumosos; plumosa e mais comprida no escutelo, metanoto, e mesepisternos (até 0,16 mm); estes por baixo com pêlos finos em gancho; pêlos da escopa brancos, curvados para baixo com cerdas não plumosas esparsas, comprimento cerca de $0,5 \mathrm{~mm}$; nos cantos laterais do propódeo como nos flancos dos mesepisternos; área basal do propódeo com pêlos plumosos e curtos; nos T1-T4 muito rala e curta, no T5 cerca de $0,35 \mathrm{~mm}$, amarelada e com curta franja preta apical; pêlos no escapo $0,12 \mathrm{~mm}$. 
Pontuação densa na fronte e entre os alvéolos; no clípeo, na área supraclipeal e nas áreas paroculares esparsa (cerca de $2 \mathrm{dp}$ ), no clípeo um pouco mais grossa, os intervalos lisos em toda cabeça, com alguns micropontos intercalados; ocelorbital com uma área muito esparsa e lisa; no vértice grossa como na face $(\varnothing 0,03-0,04$ $\mathrm{mm}$ ), nas genas esparsa (distância 1-2dp) e fraca; no mesoscuto mais fina que no vértice (cerca de $0,02 \mathrm{~mm}$ ) e muito densa (cerca de $1 / 2 \mathrm{dp}$ ), no disco um pouco menos densa, os intervalos fortemente reticulados; no escutelo esparsa (1-2dp) e mais grossa $(0,03-0,04 \mathrm{~mm})$, os intervalos com retículo fraco; no metanoto mais densa que no escutelo; nos mesepisternos relativamente esparsa, adensando-se para cima, os intervalos reticulados; adensada para baixo na face posterior do propódeo, nos cantos posteriores e laterais quase sem pontos, porém com retículo, nos flancos apenas com retículo como nos metepisternos. Em T1 fina (cerca de 0,02 mm e 1dp) mais esparsa em direção à depressão marginal, os intervalos lisos; em T2-3 adensada para a base, em direção à depressão marginal muito esparsa; em T4 mais esparsa que em T1-3; em T5 mais grossa e esparsa; as depresões marginais micro-reticuladas, em T4-5 quase desaparecendo.

Comprimento do olho $0,92 \mathrm{~mm}$, largura 0,43; olhos convergentes para baixo, distâncias interorbitais: superior $1,08 \mathrm{~mm}$, média $1,02 \mathrm{~mm}$, inferior $0,93 \mathrm{~mm}$; distância interalveolar $0,26 \mathrm{~mm}$; alveolorbital 0,26 ; alveolocelar $0,36 \mathrm{~mm} ; \varnothing$ alvéolo $0,12 \mathrm{~mm}$; interocelar $0,3 \mathrm{~mm}$; ocelorbital $0,27 \mathrm{~mm}$; $\varnothing$ ocelo médio 0,14 $\mathrm{mm}$; comprimento das suturas subantenais: a externa $0,39 \mathrm{~mm}$, a interna $0,32 \mathrm{~mm}$, largura da área subantenal $0,12 \mathrm{~mm}$; comprimento do clípeo $0,46 \mathrm{~mm}$, largura 0,76 $\mathrm{mm}$; clipeocelar $0,71 \mathrm{~mm}$; linha frontal finamente sulcada até o ocelo médio; fóvea facial (Fig. 2e) estreita, subparalela, sem pêlos, lisa, bem marcada, comprimento $0,36 \mathrm{~mm}$, largura $0,08 \mathrm{~mm}$; largura do labro $0,4 \mathrm{~mm}$, placa labral lisa, sem rúgulas, o bordo anterior em arco rebaixado, os lados convergentes (Fig. 3b), comprimento 0,2 mm, largura 0,22 mm; comprimento e $\varnothing$ máximo do escapo $0,38 \mathrm{~mm}, 0,12 \mathrm{~mm}$; comprimento dos três primeiros flagelômeros $0,12 \mathrm{~mm}, 0,07 \mathrm{~mm}, 0,09 \mathrm{~mm}, \varnothing$ do terceiro $0,13 \mathrm{~mm}$, maior $\varnothing 0,17 \mathrm{~mm}$; flagelo e pedicelo juntos cerca de $1,34 \mathrm{~mm}$; 7 hâmulos; fêmur médio em arco levemente anguloso; basitarso médio duas vezes mais longo que largo $(0,4: 0,2 \mathrm{~mm})$; área basal do propódeo semilunar com a carena média forte, alcançando o canto posterior do propódeo e descendo na face posterior como carena fina, várias rúgulas curtas laterais, subparalelas até irregulares; T2 com fóveas laterais pouco evidentes, achatadas, comprimento $0,28 \mathrm{~mm}$, largura $0,14 \mathrm{~mm}$; placa pigidial rebordada, lisa, com uma carena média fraca.

Alótipo, macho: Comprimento total aproximado 3,9 mm; asa anterior 3,4 $\mathrm{mm}$; largura da cabeça 1,46 mm; comprimento da cabeça $1,3 \mathrm{~mm}$; largura do metasoma $1,28 \mathrm{~mm}$.

Tegumento preto, com amarelo no meio do clípeo, desde a sutura epistomal até a margem anterior, os flancos pretos, duas pequenas manchas pretas perto das fóveas tentoriais anteriores; mandíbula amarela com exceção de uma mancha preta na base; antena amarelada a partir do terceiro flagelômero, mais clara por baixo, mais escura por cima; lóbulos pronotais amarelos; tégula translúcida, ocre; asas fuscas com as veias e o pterostigma pardo-méleos; tarsos dos três pares de pernas amarelos; tíbias anteriores amarelas, escuras na face posterior, as médias com uma 
estria amarela na extremidade basal, as posteriores com a metade basal amarela e metade apical castanha, os fêmures dos três pares de pernas castanhos com uma pequena mancha amarela na extremidade apical; metasoma castanho-escuro até preto com as depressões marginais dos tergos claras, translúcidas.

Pilosidade esbranquiçada, esparsa, rala; na face, no vértice e nas genas 0,18 $\mathrm{mm}$; pêlos curtos e plumosos, evidentes no pronoto; pilosidade no mesoscuto fina e curta (cerca de 0,06 mm); mais comprida e plumosa no escutelo, metanoto, e nos mesepisternos; estes no lado ventral sem pêlos em gancho; pilosidade na face posterior e nos cantos laterais do propódeo como no metanoto, área basal com pêlos plumosos evidentes; pilosidade nos tergos muito esparsa; esternos com alguns pêlos finos, adpressos, pouco evidentes; pêlos no escapo compridos, duas vezes o $\varnothing$ do escapo.

Pontuação densa, grossa e bastante uniforme em toda a cabeça, $(<1 \mathrm{dp}, \varnothing$ 0,03-0,04 mm), os intervalos lisos, reticulados somente na área supralveolar; no mesoscuto densa ( $<1 \mathrm{dp}$ ) e mais fina que na cabeça (cerca de $0,02 \mathrm{~mm}$ ), os intervalos lisos até finamente micro-reticulados; no escutelo e metanoto mais grossa, os intervalos lisos; nos mesepisternos como na cabeça; grossa e densa na face posterior do propódeo, adensada para baixo; distância dos pontos nos tergos diminuindo de T1 até T5, os intervalos lisos, no T1 até T4 relativamente densos (distância cerca de $1 \mathrm{dp}$ ), tornando-se mais esparsos em direção à depressão marginal, no T5 mais esparsa, no T6 um pouco mais grossa e um pouco mais esparsa; depressões marginais micropontuadas, no $\mathrm{T} 5$ e T6 quase desaparecendo.

Comprimento do olho $0,86 \mathrm{~mm}$, largura $0,42 \mathrm{~mm}$; olhos convergentes para baixo, distâncias interorbitais: superior $0,96 \mathrm{~mm}$, média $0,92 \mathrm{~mm}$, inferior $0,78 \mathrm{~mm}$; distância interalveolar $0,22 \mathrm{~mm}$; alveolorbital $0,22 \mathrm{~mm}$; alveolocelar $0,38 \mathrm{~mm}$; $\varnothing$ alvéolo $0,12 \mathrm{~mm}$; interocelar $0,28 \mathrm{~mm}$; ocelorbital $0,24 \mathrm{~mm}$; $\varnothing$ ocelo médio 0,14 $\mathrm{mm}$; comprimento das suturas subantenais: a externa $0,38 \mathrm{~mm}$, a interna $0,26 \mathrm{~mm}$, largura da área subantenal cerca de $0,08 \mathrm{~mm}$; comprimento do clípeo $0,4 \mathrm{~mm}$, largura $0,72 \mathrm{~mm}$; clipeocelar $0,64 \mathrm{~mm}$; linha frontal finamente sulcada até o ocelo médio, pouco evidente; fóvea facial minúscula, estreita, curta, lisa, comprimento $0,1 \mathrm{~mm}$, largura $0,04 \mathrm{~mm}$; largura do labro $0,4 \mathrm{~mm}$, placa labral lisa, sem rúgulas, truncada, os bordos aredondados, comprimento $0,13 \mathrm{~mm}$, largura $0,2 \mathrm{~mm}$; comprimento e $\varnothing$ máximo do escapo $0,28 \mathrm{~mm}, 0,14 \mathrm{~mm}$; comprimento dos três primeiros flagelômeros $0,1 \mathrm{~mm}, 0,1 \mathrm{~mm}, 0,12 \mathrm{~mm}, \varnothing$ do terceiro $0,14 \mathrm{~mm}$, maior $\varnothing 0,16 \mathrm{~mm}$; flagelo e pedicelo juntos cerca de $1,7 \mathrm{~mm} ; 5$ a 6 hâmulos; basitarso médio mais que quatro vezes mais longo que largo $(0,36: 0,08 \mathrm{~mm})$; área basal do propódeo semilunar com a carena média muito forte, alcançando o canto posterior e descendo na face posterior até a fóvea propodeal, as carenas laterais irregulares, fracas; T2 com fóveas laterais pouco evidentes, quase nulas, comprimento $0,12 \mathrm{~mm}$, largura $0,06 \mathrm{~mm}$.

Comentário. Fêmea parecida com a de P. vagabundus.

Holótipo fêmea. Brasil, Rio Grande do Sul: Capão da Canoa (Arroio Teixeira), 7-XI-1992, I. Alves dos Santos leg.; alótipo, macho com os mesmos dados do holótipo. Parátipos com os mesmos dados do holótipo, três fêmeas e 1 macho (DZUP); parátipos com os mesmos dados do holótipo 7 fêmeas; da mesma locali- 
dade e coletor do holótipo, 28-X-1993, 5 fêmeas e 1 macho (LPB); parátipo com os mesmos dados do holótipo, I fêmea (FZB); parátipos com os mesmos dados do holótipo, 3 fêmeas (MZUSP); parátipos com os mesmos dados do holótipo, duas fêmeas e 1 macho; da mesma localidade e coletor do holótipo, 28-X-1993, 1 fêmea (UFPB); parátipos da mesma localidade e coletor do holótipo, 28-X-1993, duas fềmeas (LSEA).

Flores visitadas. Acicarpha tribuloides Jussieu (Calyceraceae).

Sazonalidade. Outubro, novembro.

Distribuição geográfica. BRASIL, Rio Grande do Sul, Litoral.

Etimologia. hamus (latim) = gancho, indicando a forma dos pêlos na face ventral dos mesepisternos.

\section{Panurgillus harterae sp.n.}

Diagnose. Tíbias anteriores com uma mancha amarela na base, as tíbias médias sem mancha; pontuação no mesoscuto muito esparsa e fina; cabeça larga, os olhos levemente divergentes; placa labral curta e larga; pêlos no mesoscuto eretos, relativamente compridos (cerca do $\varnothing$ máximo do escapo); 9 a 11 hâmulos; com sulco longitudinal conspícuo acima do ocelo médio. No macho clípeo quase inteiramente amarelo com exceção de uma estreita faixa preta na margem anterior; cantos inferiores das áreas paroculares com uma mancha minúscula amarela; antena inteiramente preta; com sulco longitudinal conspícuo acima do ocelo médio; 9 hâmulos.

Holótipo fềmea. Comprimento total aproximado 7,4 mm; asa anterior 6,1 $\mathrm{mm}$; largura da cabeça $2,26 \mathrm{~mm}$; comprimento da cabeça $1,72 \mathrm{~mm}$; largura do metasoma $2,3 \mathrm{~mm}$.

Tegumento preto; tégulas escuras, pouco translúcidas; asas subhialinas com veias e pterostigma pardo-méleos, uma mancha amarela pequena na extremidade basal da costa; tíbias médias inteiramente pretas, base das tíbias anteriores com uma mancha amarela; depressões marginais dos tergos pretas.

Pilosidade levemente amarelada, esparsa, bastante comprida e plumosa na cabeça, no vértice $0,34 \mathrm{~mm}$, no mesoscuto até $0,14 \mathrm{~mm}$; pêlos mais densos no pronoto, no metanoto e nos flancos dos mesepisternos, até $0,38 \mathrm{~mm}$; mesepisterno sem pêlos em gancho; escopa inteiramente branca, com cerdas não plumosas, relativamente esparsas, comprimento $0,5 \mathrm{~mm}$; no $\mathrm{T} 5$ com cerdas escuras, $0,44 \mathrm{~mm}$; T5 com franja apical escura; pêlos no escapo até $0,14 \mathrm{~mm}$.

Pontuação muito fina na metade superior da face, no vértice e nas genas (cerca de $0,02 \mathrm{~mm}, 2-3 \mathrm{dp}$ ), os intervalos entre os pontos com retículo forte; a metade inferior da face com pontos mais grossos e com intervalos lisos (cerca de $2 \mathrm{dp}$ ), nas áreas paroculares com alguns micropontos intercalados; área supraclipeal quase sem pontos; no mesoscuto muito fina e esparsa $(\leq 0,02 \mathrm{~mm}$, $\varnothing 2 \mathrm{dp})$, os intervalos reticulados; no escutelo mais grossa e esparsa, no metanoto densa; nos mesepisternos esparsa, os intervalos reticulados, na face posterior do propódeo muito fraca, faltando na parte superior; em T1-4 muito fina (cerca de 2dp), no T1 um pouco mais 
esparsa, no T5 mais grossa e mais esparsa; os intervalos de todos os tergos reticulados; depressões marginais reticuladas.

Comprimento do olho $1,16 \mathrm{~mm}$, largura $0,56 \mathrm{~mm}$; distâncias interorbitais: superior $1,42 \mathrm{~mm}$, média $1,5 \mathrm{~mm}$, inferior $1,54 \mathrm{~mm}$; distância interalveolar 0,36 $\mathrm{mm}$; alveolorbital $0,38 \mathrm{~mm}$; alveolocelar $0,5 \mathrm{~mm}$; $\varnothing$ alvéolo $0,15 \mathrm{~mm}$; interocelar $0,36 \mathrm{~mm}$; ocelorbital $0,4 \mathrm{~mm} ; \varnothing$ ocelo médio $0,18 \mathrm{~mm}$; comprimento das suturas subantenais: a externa $0,4 \mathrm{~mm}$, a interna $0,32 \mathrm{~mm}$, suturas subantenais convergentes para baixo, largura máxima da área subantenal $0,17 \mathrm{~mm}$; comprimento do clípeo $0,62 \mathrm{~mm}$, largura $1,44 \mathrm{~mm}$; clipeocelar $0,8 \mathrm{~mm}$; linha frontal sulciforme chegando até o ocelo médio; sulco longitudinal acima do ocelo médio na área inter-ocelar; fóvea facial oval, um pouco alargada em cima, bem marcada, com alguns pêlos, comprimento $0,44 \mathrm{~mm}$, largura $0,14 \mathrm{~mm}$; largura do labro $0,86 \mathrm{~mm}$, placa labral curta e larga, as margens laterais convergentes, margem anterior quase reta, comprimento $0,2 \mathrm{~mm}$, largura $0,38 \mathrm{~mm}$; escapo: comprimento e $\varnothing$ máximo $0,56 \mathrm{~mm}$, $0,14 \mathrm{~mm}$; comprimento dos três primeiros flagelômeros $0,19 \mathrm{~mm}, 0,14 \mathrm{~mm}, 0,14$ $\mathrm{mm}, \varnothing$ do terceiro $0,17 \mathrm{~mm}$, maior $\varnothing 0,19 \mathrm{~mm}$; flagelo e pedicelo juntos cerca de 2,0 mm; 9 a 11 hâmulos; fêmur médio arredondado; basitarso médio duas até três vezes mais longo que largo $(0,72: 0,3 \mathrm{~mm})$; área basal do propódeo com limites indefinidos, apenas com uma curta carena média e algumas carenas obsoletas laterais; T2 com fóveas laterais pouco evidentes, rasas, comprimento $0,4 \mathrm{~mm}$, largura $0,2 \mathrm{~mm}$; placa pigidial rebordada, com estrias transversais.

Alótipo, macho: Comprimento total aproximado $6,0 \mathrm{~mm}$; asa anterior 5,5 $\mathrm{mm}$; largura da cabeça $1,94 \mathrm{~mm}$; comprimento da cabeça $1,5 \mathrm{~mm}$; largura do metasoma $1,74 \mathrm{~mm}$.

Tegumento preto, clípeo quase inteiramente amarelo, com exceção de uma estreita faixa preta na margem anterior e uma pequena mancha escura a cada lado perto da fóvea tentorial; cantos inferiores das áreas paroculares com uma mancha minúscula amarela; antenas inteiramente pretas; asas subhialinas com veias e pterostigma castanhos; mancha amarela pequena na base das tíbias anteriores e médias; terço basal das tíbias posteriores amarelo; tarsos de todas pernas castanhoclaros.

Pilosidade esbranquiçada, esparsa, relativamente comprida na cabeça, escutelo, metanoto e mesepisternos (até $0,36 \mathrm{~mm}$ ); no mesoscuto mais curta (até 0,12 $\mathrm{mm}$ ); nos tergos muito rala e curta; pêlos finos e curtos, adpressos em E2-E5, pouco evidentes; pêlos no escapo longos, até $0,22 \mathrm{~mm}$.

Pontuação na cabeça como na fêmea, os intervalos entre os pontos reticulados em toda a cabeça, mais evidentes na metade superior da face; no mesoscuto fina $(0,02 \mathrm{~mm})$, um pouco mais densa do que na fêmea (1-2dp), os intervalos fortemente reticulados; no escutelo mais grossa e esparsa, no metanoto densa, nos mesepisternos esparsa, os intervalos reticulados; na face posterior do propódeo muito fraca, faltando na parte superior, porém com retículo evidente; em T1-4 muito fina e pouco evidente (cerca de 1-2dp), em T5 um pouco mais grossa e mais esparsa, em T6 grossa e esparsa; os intervalos de todos os tergos fortemente reticulados; depressões marginais reticuladas. 
Comprimento do olho $1,0 \mathrm{~mm}$, largura $0,52 \mathrm{~mm}$; olhos levemente divergentes para baixo, distâncias interorbitais: superior $1,28 \mathrm{~mm}$, média $1,32 \mathrm{~mm}$, inferior $1,4 \mathrm{~mm}$; distância interalveolar $0,3 \mathrm{~mm}$; alveolorbital $0,34 \mathrm{~mm}$; alveolocelar 0,48 $\mathrm{mm}$; $\varnothing$ alvéolo $0,14 \mathrm{~mm}$; interocelar $0,3 \mathrm{~mm}$; ocelorbital $0,4 \mathrm{~mm}$; $\varnothing$ ocelo médio $0,16 \mathrm{~mm}$; comprimento das suturas subantenais: a externa $0,34 \mathrm{~mm}$, a interna 0,32 $\mathrm{mm}$, largura máxima da área subantenal $0,16 \mathrm{~mm}$, suturas subantenais convergentes para baixo; comprimento do clípeo $0,56 \mathrm{~mm}$, largura $1,28 \mathrm{~mm}$; clipeocelar $0,7 \mathrm{~mm}$; linha frontal pouco evidente; um sulco longitudinal acima do ocelo médio na área interocelar; fóvea facial pequena, um pouco alargada na metade superior, comprimento $0,28 \mathrm{~mm}$, largura $0,11 \mathrm{~mm}$; largura do labro aproximadamente $0,62 \mathrm{~mm}$, placa labral lisa, larga e curta (comprimento $0,14 \mathrm{~mm}$, largura $0,4 \mathrm{~mm}$ ), os lados convergentes, o bordo anterior quase reto; escapo: comprimento e $\varnothing$ máximo 0,44 $\mathrm{mm}, 0,15 \mathrm{~mm}$; comprimento dos três primeiros flagelômeros $0,18 \mathrm{~mm}, 0,14 \mathrm{~mm}$, $0,16 \mathrm{~mm}, \varnothing$ do terceiro $0,17 \mathrm{~mm}$, maior $\varnothing 0,18 \mathrm{~mm}$; flagelo e pedicelo juntos cerca de 2,3 mm; 9 hâmulos; basitarso médio quatro vezes mais longo que largo $(0,54$ : $0,14 \mathrm{~mm}$ ); área basal do propódeo com rúgulas um pouco mais evidentes que na fêmea; T2 com fóveas laterais pequenas, comprimento $0,16 \mathrm{~mm}$, largura $0,1 \mathrm{~mm}$.

Holótipo fêmea. Brasil, Rio Grande do Sul: São Francisco de Paula (Pró-Mata), 07-X-1996, Birgit Harter leg.; alótipo, macho, da mesma localidade e coletor, 17-X-1996 (DZUP). Parátipos da mesma localidade e coletor do holótipo, 17-X-1996, 1 fêmea; 29-X-1996, 1 fêmea (LPB); parátipo com os mesmos dados do alótipo, 1 fêmea (UFPB); parátipo da mesma localidade e coletor do holótipo, 17-X-1996, 1 fêmea (LSEA).

Flores visitadas. Baccharis uncinella DC.; B. crispa Spreng. (Asteraceae)

Sazonalidade. Outubro

Distribuição geográfica. BRASIL, Rio Grande do Sul, Planalto.

Etimologia. Dedicado à pesquisadora Birgit Harter que coletou os exemplares estudados.

Comentário. Maior espécie de Panurgillus, parecida com P. flavitarsis, com a qual ocorre simpatricamente.

\section{Panurgillus holostictus sp.n.}

Diagnose. Pontuação relativamente grossa e densa em todo corpo; T2 com fóveas laterais bem marcadas, profundas; olhos convergentes em baixo; tíbias anteriores e médias com uma mancha amarela na base; pêlos no mesoscuto muito curtos.

Holótipo fêmea. Comprimento total aproximado $5,5 \mathrm{~mm}$; asa anterior 4,2 $\mathrm{mm}$; largura da cabeça $1,68 \mathrm{~mm}$; comprimento da cabeça $1,44 \mathrm{~mm}$; largura do metasoma $1,78 \mathrm{~mm}$.

Tegumento preto com o flagelo amarelo por baixo; tégula ocre, translúcida; asas ligeiramente fuscas com veias e pterostigma castanho-escuros, uma mancha amarela na base da $\mathrm{C}+\mathrm{Sc}$, estendendo-se até o pterostigma; pernas castanho-escuras, quase pretas com uma mancha amarela pequena na base das tíbias anteriores $\mathrm{e}$ 
médias; metasoma castanho-escuro até preto; depressões marginais dos tergos parcialmente translúcidas na margem posterior, quase inteiramente pretas.

Pilosidade esbranquiçada, esparsa e rala; na face, no vértice e nas genas cerca de $0,12 \mathrm{~mm}$, no mesoscuto e no escutelo curta (cerca de $0,04 \mathrm{~mm}$ ), um pouco mais comprida no metanoto; pêlos plumosos mais evidentes nos mesepisternos (cerca de $0,18 \mathrm{~mm}$ ); mesepisterno por baixo com pêlos finos, um pouco recurvados; pêlos da escopa brancos com cerdas não plumosas esparsas, comprimento cerca de $0,45 \mathrm{~mm}$; pêlos na área basal do propódeo como no metanoto, nos cantos laterais como nos mesepisternos; T1-4 com pilosidade muito rala e curta, em T5 pêlos amarelados até $0,35 \mathrm{~mm}$ e com curta franja apical, amarela; pêlos no escapo até $0,08 \mathrm{~mm}$.

Pontuação bastante densa em todo o corpo; na fronte muito densa $(<1 / 2 \mathrm{dp}$, $\varnothing$ cerca de $0,03 \mathrm{~mm}$ ); na metade inferior da face um pouco mais grossa (cerca de $0,04 \mathrm{~mm}$ ), e mais esparsa, intervalos com alguns micropontos intercalados; os intervalos entre os pontos reticulados, lisos somente no clípeo; no vértice e nas genas muito densa como na fronte, tornando-se mais esparsa para baixo; no mesoscuto densa ( $1 / 2 \mathrm{dp})$ e uniforme, os intervalos com retículo forte; no escutelo e metanoto um pouco mais grossa e mais esparsa, alguns intervalos um pouco maiores que os pontos; nos metepisternos muito fina e densa; na face posterior do propódeo densa, nos flancos um pouco mais esparsa; em T1-T3 forte e densa ( $<1 \mathrm{dp})$, um pouco mais esparsa em direção às depressões marginais, os intervalos finamente reticulados; em T4 um pouco mais fina e esparsa, em T5 mais esparsa (até $3 \mathrm{dp}$ ) os intervalos com retículo evidente; depressões marginais densamente micropontuadas.

Comprimento do olho $1,08 \mathrm{~mm}$, largura $0,55 \mathrm{~mm}$; olhos convergentes para baixo, distâncias interorbitais: superior $1,02 \mathrm{~mm}$, média $0,95 \mathrm{~mm}$, inferior $0,92 \mathrm{~mm}$; distância interalveolar $0,2 \mathrm{~mm}$; alveolorbital $0,26 \mathrm{~mm}$; alveolocelar $0,46 \mathrm{~mm} ; \varnothing$ alvéolo $0,14 \mathrm{~mm}$; interocelar $0,28 \mathrm{~mm}$; ocelorbital $0,3 \mathrm{~mm}$; $\varnothing$ ocelo médio 0,13 $\mathrm{mm}$; comprimento das suturas subantenais: a externa $0,41 \mathrm{~mm}$, a interna $0,36 \mathrm{~mm}$, largura da área subantenal $0,12 \mathrm{~mm}$; comprimento do clípeo $0,4 \mathrm{~mm}$, largura 0,82 $\mathrm{mm}$; clipeocelar $0,84 \mathrm{~mm}$; linha frontal em forma de sulco entre as antenas, o terço superior com carena pouco evidente; fóvea facial estreita, bem marcada, lisa, porém mate, sem pêlos, comprimento $0,26 \mathrm{~mm}$, largura $0,09 \mathrm{~mm}$; largura do labro $0,5 \mathrm{~mm}$, placa labral lisa, sem rúgulas, quase tão longa como larga, o bordo anterior em arco rebaixado, comprimento $0,26 \mathrm{~mm}$, largura $0,30 \mathrm{~mm}$; comprimento e $\varnothing$ máximo do escapo $0,4 \mathrm{~mm}, 0,13 \mathrm{~mm}$; flagelo ligeiramente clavado, comprimento dos três primeiros flagelômeros $0,14 \mathrm{~mm}, 0,07 \mathrm{~mm}, 0,08 \mathrm{~mm}, \varnothing$ do terceiro $0,14 \mathrm{~mm}$, maior $\varnothing 0,2 \mathrm{~mm}$; flagelo e pedicelo juntos $1,46 \mathrm{~mm} ; 8$ a 9 hâmulos; fêmur médio com carena, formando ângulo evidente; basitarso médio duas vezes mais longo que largo $(0,44: 0,22 \mathrm{~mm})$; área basal do propódeo semilunar, com rúgulas fortes, irregulares, alcançando o canto posterior do propódeo; T2 com fóveas laterais bem marcadas, evidentes, comprimento $0.2 \mathrm{~mm}$ e 0,07 de largura; placa pigidial com uma carena média baixa e grossa, lisa.

Macho desconhecido.

Holótipo fêmea. Brasil, Rio Grande do Sul: Caçapava do Sul (Guaritas), 07-XI-1991, C. Schlindwein leg. (DZUP). Parátipo da mesma localidade e coletor, 6-XII-1992, 1 fềmea (LPB); parátipo da mesma localidade e coletor, 9-XI-1991 (LSEA). 
Flores visitadas. Perezia kingii Baker (Asteraceae), Geranium robertianum L. (Geraniaceae), Verbena montevidensis Spreng. (Verbenaceae).

Sazonalidade. Novembro, dezembro

Distribuição geográfica. BRASIL, Rio Grande do Sul, Serra do Sudeste.

Etimologia. $0 ̋ \lambda \circ s=$ todo, $\sigma \tau \iota \kappa \tau$ ós = pontuado. O nome refere-se a pontuação forte e uniforme em quase todo o corpo.

\section{Panurgillus pereziae sp.n. \\ Figs $1 e-f, 3 e, 4 a, 4 c$}

Diagnose. Fêmeas com uma mancha amarela no disco do clípeo; mandíbulas castanhas; lóbulos pronotais amarelos; tíbias anteriores e médias com uma mancha amarela na base; mesoscuto com pontuação densa e pilosidade curta; fêmures médios com um dente na face ventral; T2 com fóveas laterais bem marcadas, profundas. Macho com o terço inferior da face amarela, ápices dos fêmures com mancha amarela; tíbias anteriores amarelas, metade das tíbias médias e posteriores amarelas.

Holótipo fêmea. Comprimento total aproximado $5,5 \mathrm{~mm}$; asa anterior 4,25 $\mathrm{mm}$; largura da cabeça $1,73 \mathrm{~mm}$; comprimento da cabeça $1,48 \mathrm{~mm}$; largura do metasoma $1,68 \mathrm{~mm}$.

Tegumento preto com uma mancha amarela grande em toda a parte central do clípeo, da sutura epistomal até a margem anterior, estreitada para baixo, os lados do clípeo pretos; mandíbulas castanhas; flagelo amarelo por baixo; os lóbulos pronotais amarelos; tégula amarela, translúcida; asas subhialinas com as veias e o pterostigma pardo-méleos; uma mancha pardo-amarelada na base da $\mathrm{C}+\mathrm{Sc}$; uma mancha amarela na base das tíbias anteriores e médias; tarsos anteriores amarelados; depressões marginais dos tergos translúcidas.

Pilosidade esbranquiçada, rala e curta; pêlos amarelos nos basitarsos anteriores e no T5; comprimento no vértice e nas genas até $0,25 \mathrm{~mm}$; um pouco mais evidente e plumosa no pronoto; muito curta no mesoscuto e no escutelo (cerca de $0,04 \mathrm{~mm}$ ); nos mesepisternos até $0,18 \mathrm{~mm}$, no lado ventral sem pêlos em gancho; escopa inteiramente branca com cerdas pouco plumosas, moderadamente numerosas, comprimento cerca de $0,32 \mathrm{~mm}$; branca, plumosa, relativamente longa na área basal do propódeo; no T5 até $0,4 \mathrm{~mm}$; T5 com franja preta de pêlos curtos; pêlos no escapo $0,16 \mathrm{~mm}$.

Pontuação na fronte fina e densa ( $\varnothing$ cerca de $0,02 \mathrm{~mm},<1 \mathrm{dp}$ ), os intervalos reticulados; na metade inferior da face um pouco mais grossa (até $0,04 \mathrm{~mm}$ no clípeo) e mais esparsa (1-3dp), os intervalos com alguns micropontos intercalados, reticulados na área supraclipeal e nas áreas paroculares, lisos no clípeo; nas genas e no vértice muito densa e fina, os intervalos reticulados (cerca de $1 / 2 \mathrm{dp}$ ); no mesoscuto muito fina $(0,02 \mathrm{~mm})$ e densa, os intervalos reticulados (cerca de $1 / 2 \mathrm{dp}$ ); no escutelo um pouco mais grossa e um pouco mais esparsa que no mesoscuto, intervalos reticulados; nos mesepisternos relativamente densa (cerca de 1dp), adensada para cima; nos metepisternos densa; nos flancos, nos cantos e na face posterior 
do propódeo fina e densa, os intervalos reticulados; em T2-T3 fina $(<0,2 \mathrm{~mm})$ e densa (cerca de $1 \mathrm{dp}$ ), ficando mais esparsa em direção à depressão marginal, em T1 um pouco mais grossa e esparsa, os intervalos reticulados; em T4 um pouco mais fina e esparsa, em T5 grossa (cerca de $0,03 \mathrm{~mm}$ ) e esparsa (cerca de $3 \mathrm{dp}$ ); depressões marginais densamente micropontuadas.

Comprimento do olho $1,0 \mathrm{~mm}$, largura $0,56 \mathrm{~mm}$; olhos levemente convergentes para baixo, distâncias interorbitais: superior $1,04 \mathrm{~mm}$, média $1,0 \mathrm{~mm}$, inferior $0,96 \mathrm{~mm}$; distância interalveolar $0,24 \mathrm{~mm}$; alveolorbital $0,28 \mathrm{~mm}$; alveolocelar 0,47 $\mathrm{mm}$; $\varnothing$ alvéolo $0,12 \mathrm{~mm}$; interocelar $0,26 \mathrm{~mm}$; ocelorbital $0,3 \mathrm{~mm}$; $\varnothing$ ocelo médio $0,14 \mathrm{~mm}$; comprimento das suturas subantenais: a externa $0,42 \mathrm{~mm}$, a interna 0,3 $\mathrm{mm}$, largura da área subantenal $0,15 \mathrm{~mm}$; comprimento do clípeo $0,44 \mathrm{~mm}$, largura $0,94 \mathrm{~mm}$; clipeocelar $0,72 \mathrm{~mm}$; linha frontal pouco evidente, sulciforme em baixo e desaparecendo nos dois terços superiores; fóvea facial (Fig. 1f) estreita, lisa, bem marcada, comprimento $0,3 \mathrm{~mm}$, largura $0,1 \mathrm{~mm}$; largura do labro $0,46 \mathrm{~mm}$, placa labral lisa, sem rúgulas, tão comprida como larga (Fig. 3e), comprimento $0,26 \mathrm{~mm}$, largura $0,3 \mathrm{~mm}$, ápice arredondado; escapo: comprimento e $\varnothing$ máximo $0,4 \mathrm{~mm}$, $0,14 \mathrm{~mm}$; flagelo ligeiramente clavado, comprimento dos três primeiros flagelômeros $0,1 \mathrm{~mm}, 0,07 \mathrm{~mm}, 0,07 \mathrm{~mm}, \varnothing$ do terceiro $0,14 \mathrm{~mm}, \varnothing$ máximo $0,17 \mathrm{~mm}$; flagelo e pedicelo juntos $1,4 \mathrm{~mm} ; 7$ a 8 hâmulos; fêmur médio com ângulo pronunciado (Fig. 4c); basitarso médio 2-3 vezes mais longo que largo (0,5: 0,2 $\mathrm{mm}$ ); área basal do propódeo semilunar, somente com uma carena média fina, com pontuação forte e densa e retículo forte (Fig. 4a); T2 com fóveas laterais evidentes, comprimento $0,28 \mathrm{~mm}$, largura $0,12 \mathrm{~mm}$; placa pigidial rebordada, lisa na parte posterior, reticulada na parte anterior, com uma carena mediana, baixa e larga.

Alótipo macho. Comprimento total aproximado $4,95 \mathrm{~mm}$; asa anterior 4,25 $\mathrm{mm}$; largura da cabeça $1,72 \mathrm{~mm}$; comprimento da cabeça $1,46 \mathrm{~mm}$; largura do metasoma $1,38 \mathrm{~mm}$.

Tegumento preto; clípeo amarelo menos duas pequenas manchas pretas, uma a cada lado, perto da fóveas tentoriais anteriores; áreas paroculares inferiores amarelas; flagelo amarelo por baixo; lóbulos pronotais amarelos com pequena mancha preta; tégula amarelada, translúcida; asas ligeiramente escurecidas com as veias e pterostigma amarelados, uma mancha amarela na base da $\mathrm{C}+\mathrm{Sc}$; ápice dos fêmures 1-3 amarelo; tibia anterior amarela com a face interna escura; metade superior da tíbia média e posterior amarela; tarsos de todos os pares de pernas amarelos; depressões marginais dos tergos transparentes.

Pilosidade parecida com a da fêmea, mais evidente no terço posterior do escutelo; sem pêlos adpressos nos esternos; pêlos no escapo até $0,2 \mathrm{~mm}$.

Pontuação na fronte fina e densa ( $\varnothing$ cerca de $0,02 \mathrm{~mm},<1 \mathrm{dp}$ ), os intervalos reticulados; na metade inferior da face um pouco mais grossa (até $0,04 \mathrm{~mm}$ no clípeo) e mais esparsa (1-2dp, no clípeo até $4 \mathrm{dp})$, os intervalos lisos na área supraclipeal, no clípeo e nas áreas paroculares inferiores; nas genas e no vértice muito densa e fina ( $<1 \mathrm{dp})$, os intervalos reticulados; no mesoscuto muito fina $(0,02$ $\mathrm{mm}$ ) e densa $(<1 \mathrm{dp})$, os intervalos finamente reticulados; no escutelo mais grossa e mais esparsa que no mesoscuto, intervalos lisos; no metanoto mais densa; nos 
mesepisternos esparsa, intervalos fortemente reticulados; nos metepisternos fina, densa; nos cantos e na face posterior do propódeo fina e densa, os intervalos reticulados; em T2-T5 fina (cerca de 0,2 mm) e densa ( $\leq 1 \mathrm{dp}$ ), mais esparsa em direção à depressão marginal, em T1 levemente mais grossa e esparsa; em T6 esparsa (cerca de 3dp); os intervalos nos tergos finamente reticulados; as depressões marginais micropontuadas.

Comprimento do olho $1,0 \mathrm{~mm}$, largura $0,6 \mathrm{~mm}$; olhos convergentes para baixo, distâncias interorbitais: superior $1,14 \mathrm{~mm}$, média $0,98 \mathrm{~mm}$, inferior $0,9 \mathrm{~mm}$; distância interalveolar $0,24 \mathrm{~mm}$; alveolorbital $0,21 \mathrm{~mm}$; alveolocelar $0,44 \mathrm{~mm}$; $\varnothing$ alvéolo $0,13 \mathrm{~mm}$; interocelar $0,28 \mathrm{~mm}$; ocelorbital $0,36 \mathrm{~mm}$; $\varnothing$ ocelo médio 0,15 $\mathrm{mm}$; suturas subantenais: a externa $0,34 \mathrm{~mm}$, a interna $0,28 \mathrm{~mm}$, largura da área subantenal $0,11 \mathrm{~mm}$; comprimento do clípeo $0,44 \mathrm{~mm}$, largura $0,82 \mathrm{~mm}$; clipeocelar $0,70 \mathrm{~mm}$; linha frontal pouco evidente, em forma de sulco entre as antenas, careniforme até o ocelo médio; fóvea facial estreita, lisa, bem marcada, comprimento $0,23 \mathrm{~mm}$, largura $0,1 \mathrm{~mm}$; largura do labro $0,36 \mathrm{~mm}$, placa labral pequena, lisa, sem rúgulas (comprimento $0,2 \mathrm{~mm}$, largura $0,22 \mathrm{~mm}$ ); escapo: comprimento e $\varnothing$ máximo $0,3 \mathrm{~mm}, 0,16 \mathrm{~mm}$; flagelo ligeiramente clavado, comprimento dos três primeiros flagelômeros $0,16 \mathrm{~mm}, 0,08,1,0 \mathrm{~mm}, \varnothing$ do terceiro $0,18 \mathrm{~mm}, \varnothing$ máximo $0,22 \mathrm{~mm}$; flagelo e pedicelo juntos $1,6 \mathrm{~mm} ; 6$ a 7 hâmulos; fềmur médio sem ângulo; basitarso médio quase 4 vezes mas longo que largo $(0,46: 0,12 \mathrm{~mm})$; área basal do propódeo semilunar, com algumas carenas curtas, a média não mais forte que as laterais, fortemente pontuada e com pilosidade plumosa; T2 com fóveas laterais evidentes, comprimento $0,2 \mathrm{~mm}$, largura $0,08 \mathrm{~mm}$.

Holótipo fêmea. Brasil, Rio Grande do Sul: Caçapava do Sul (Guaritas) 30-IX-1992, C. Schlindwein leg,; -alótipo, macho da mesma localidade e coletor do holótipo, 11-X-1993. Parátipos da mesma localidade e coletor do holótipo, 08-X-1993, três fêmeas; 10-X-1992, 1 fêmea (DZUP); parátipos com os mesmos dados do holótipo, 2 fêmeas; Santana da Boa Vista (Minas de Camaquã), 30-IX1990, C. Schlindwein leg., 1 macho; da mesma localidade e coletor do holótipo, 08-X-1993, 5 fềmeas; 09-X-1993, duas fêmeas; 22-X-1994, duas fêmeas; 06-XI1994, duas fêmeas; 09-XI-1991, 1 fêmea (LPB); parátipos com os mesmos dados do holótipo, 2 fêmeas; 08-X-1993, duas fêmeas (MZUSP); parátipos, com os mesmos dados do holótipo, 1 fêmea; da mesma localidade e coletor, 9-XI-1991, 1 fêmea; 10-X-1992, 1 fêmea (FZB); parátipos com os mesmos dados do holótipo, três fêmeas; 10-X-1991, 1 fềmea; 10-X-1992, 1 fêmea; 11-X-1993, 1 macho; 22-X-1994, duas fêmeas (UFPB); parátipos com os mesmos dados do holótipo, três fềmeas (LSEA).

Flores visitadas. Perezia kingii Baker, Pamphalea heterophylla Lessing (Asteraceae-Mutisieae), Nothoscordum inodorum (Soland.) Nichol. (Liliaceae), Glandularia sp. (Verbenaceae).

Sazonalidade. Setembro até novembro.

Distribuição geográfica. BRASIL, Rio Grande do Sul, Serra do Sudeste (Guaritas).

Etimologia. $\mathrm{O}$ nome é alusivo às plantas preferencialmente visitadas. 


\section{Panurgillus plumosulus sp.n.}

Diagnose. Pêlos compridos no mesoscuto e na face; fóveas faciais alargadas, rasas; olhos paralelos; placa labral larga, quase truncada; pontuação esparsa no mesoscuto; área basal do propódeo quase sem rúgulas laterais; tíbias anteriores e médias com mancha amarela na base, podendo faltar nas médias; T1-T4 quase sem pontos, porém com retículo.

Holótipo fềmea. Comprimento total aproximado $6,1 \mathrm{~mm}$; asa anterior 4,52 $\mathrm{mm}$; largura da cabeça 1,96 mm; comprimento da cabeça $1,62 \mathrm{~mm}$; largura do metasoma $1,96 \mathrm{~mm}$.

Tegumento preto; o flagelo amarelo por baixo; tégula ocre, translúcida, anteriormente escura; asas subhialinas, com veias e pterostigma pardo-méleos; uma mancha amarela na base da $\mathrm{C}+\mathrm{Sc}$; pernas castanhas; manchas amarelas muito pequenas na base das tíbias anteriores e médias (nas pernas médias às vezes pouco evidentes); depressões marginais dos tergos translúcidas.

Pilosidade esbranquiçada, esparsa e rala; amarelada nos tarsos; comprida e plumosa na cabeça e no mesosoma (até $0,36 \mathrm{~mm}$, na cabeça um pouco mais curta); mesepisterno por baixo sem pêlos em gancho; escopa branca com cerdas não plumosas esparsas, comprimento $0,48 \mathrm{~mm}$; pilosidade dos tergos muito rala, com alguns pêlos compridos aos lados; no T5 $0,48 \mathrm{~mm}$ e com curta franja apical, amarelo-escura; pêlos no escapo até $0,26 \mathrm{~mm}$.

Pontuação na fronte e nas áreas paroculares fina e esparsa ( $\varnothing$ cerca de 0,02 $\mathrm{mm}$, até $3 \mathrm{dp}$ ), os intervalos fortemente reticulados; clípeo e área supraclipeal com retículo mais brilhante; na metade inferior da face mais grossa, muito esparsa; área supraclipeal quase sem pontos; no vértice e nas genas muito fina e esparsa, os intervalos fortemente reticulados; no mesoscuto e escutelo fina (cerca de $0,02 \mathrm{~mm}$ ) e muito esparsa (até $4 \mathrm{dp}$ ), com retículo forte; no metanoto um pouco mais densa que no mesoscuto; nos metepisternos com microcarenas longitudinais; nos flancos e na superfície posterior do propódeo bastante uniforme, os intervalos com retículo muito forte; nos tergos extremamente fina e esparsa, os intervalos finamente reticulados; em T2-T4 2-3dp, em T1 mais esparsa, em T5 um pouco mais grossa; depressões marginais dos tergos finamente reticuladas.

Comprimento do olho $1,08 \mathrm{~mm}$; largura $0,57 \mathrm{~mm}$; olhos subparalelos, distâncias interorbitais: superior $1,28 \mathrm{~mm}$, média $1,28 \mathrm{~mm}$, inferior $1,32 \mathrm{~mm}$; distância interalveolar $0,34 \mathrm{~mm}$; alveolorbital $0,34 \mathrm{~mm}$; alveolocelar $0,44 \mathrm{~mm}$; $\varnothing$ alvéolo $0,16 \mathrm{~mm}$; interocelar $0,36 \mathrm{~mm}$; ocelorbital $0,35 \mathrm{~mm}$; $\varnothing$ ocelo médio 0,15 $\mathrm{mm}$; comprimento das suturas subantenais: a externa $0,5 \mathrm{~mm}$, a interna $0,38 \mathrm{~mm}$, largura da área subantenal $0,16 \mathrm{~mm}$; comprimento do clípeo $0,46 \mathrm{~mm}$, largura 1,26 $\mathrm{mm}$; clipeocelar $0,74 \mathrm{~mm}$; linha frontal sulciforme entre as antenas, careniforme na metade superior até o ocelo médio; fóvea facial rasa, alargada, comprimento 0,26 $\mathrm{mm}$, largura $0,12 \mathrm{~mm}$, com alguns pontos pilígeros; largura do labro $0,64 \mathrm{~mm}$, placa labral lisa e com vestígios de algumas pequenas rúgulas radiantes basais, os bordos laterais ligeiramente convergentes para o ápice, o bordo apical truncado, comprimento $0,3 \mathrm{~mm}$, largura $0,38 \mathrm{~mm}$; escapo: comprimento e $\varnothing$ máximo $0,44 \mathrm{~mm}, 0,12$ 
$\mathrm{mm}$; flagelo clavado, comprimento dos três primeiros flagelômeros $0,18 \mathrm{~mm}, 0,09$ $\mathrm{mm}, 0,08 \mathrm{~mm}, \varnothing$ do terceiro $0,15 \mathrm{~mm}$, maior $\varnothing 0,2 \mathrm{~mm}$; flagelo e pedicelo juntos 1,52 mm; 7 a 9 hâmulos; fêmur médio com ângulo evidente; basitarso médio cerca de duas vezes mais longo que largo $(0,58: 0,26 \mathrm{~mm})$; área basal do propódeo com limites indefinidos, apenas com uma curta carena média e algumas carenas obsoletas laterais; T2 com as fóveas laterais pouco evidentes, comprimento $0,28 \mathrm{~mm}$, largura $0,1 \mathrm{~mm}$; placa pigidial fracamente rebordada, com estrias transversais.

Macho não conhecido.

Holótipo fêmea. BrasiL, Rio Grande do Sul: Santana da Boa Vista (Minas de Camaquã), 30-IX-1990, C. Schlindwein leg. . Parátipo com os mesmos dados do holótipo, 1 fêmea (DZUP); parátipos com os mesmos dados do holótipo, 1 fêmea; 22-IX-1991, 1 fêmea (LPB); parátipo com os mesmos dados do holótipo, 1 fêmea (FZB); parátipo de Caçapava do Sul, Guaritas, 06-IX-1991, C. Schlindwein leg., 1 fêmea (MZUSP); parátipo com os mesmos dados do holótipo, 1 fêmea (UFPB); parátipo, Caçapava do Sul (Guaritas), 22-IX-1991, C. Schlindwein leg., 1 fêmea (LSEA).

Flores visitadas. Oxalis brasiliensis Loddiges, $O$. eriocarpa St. Hil., $O$. sellowiana Zucc. (Oxalidaceae).

Sazonalidade. Maio até outubro.

Distribuição geográfica. BRASIL, Rio Grande do Sul, Serra do Sudeste.

Etimologia. pluma $($ latim $)=$ pena. O nome refere-se aos poucos pêlos longos, curtíssimo-plumosos na cabeça e no mesosoma.

Comentário. As fêmeas são muito parecidas com as de P. reticulatus, porém diferem pelos seguintes carateres: pêlos mais compridos e plumosos no mesoscuto e na face; clípeo e área supraclipeal com os intervalos quase lisos, o retículo muito fraco; pêlos no escapo mais compridos; área basal do propódeo quase sem carenas; base das tíbias anteriores e médias geralmente com uma mancha amarela pequena; nos tergos o retículo mais fraco e a pontuação mais fina; fóvea facial pouco destacada, fraca, mais curta; depressões marginais dos tergos translúcidas.

\section{Panurgillus politus sp.n.}

Diagnose. T1 quase sem pontos, liso e brilhante, T2-T4 pontuado; 6 a 7 hâmulos; olhos convergentes para baixo; mesoscuto com pontuação densa, reticulado entre os pontos; pêlos em gancho no lado ventral dos mesepisternos; tíbias anteriores e médias com mancha amarela na base.

Holótipo fêmea. Comprimento total aproximado 4,9 mm; asa anterior 4,35 $\mathrm{mm}$; largura da cabeça 1,6 mm; comprimento da cabeça $1,4 \mathrm{~mm}$; largura do metasoma $1,52 \mathrm{~mm}$.

Tegumento preto; os últimos flagelômeros amarelados por baixo; tégula castanha, translúcida; asas subhialinas com veias e pterostigma pardo-méleos, uma linha amarela na base da $\mathrm{C}+\mathrm{Sc}$; manchas amarelas muito pequenas na base das tíbias anteriores e médias; tarsos de todos os pares escuros; depressões marginais dos tergos pretos com a extremidade um pouco translúcida. 
Pilosidade esbranquiçada, rala e curta; amarelada nos tarsos anteriores; na face, no vértice e nas genas cerca de $0,2 \mathrm{~mm}$, no mesoscuto curta (cerca de 0,08 $\mathrm{mm}$ ), um pouco mais longa no escutelo; lado ventral dos mesepisternos com pêlos finos em gancho; escopa inteiramente branca com cerdas não plumosas moderadamente numerosas, comprimento $0,35 \mathrm{~mm}$; no T5 $0,36 \mathrm{~mm}$ e com curta franja apical amarela; pêlos no escapo até $0,12 \mathrm{~mm}$.

Pontuação na fronte fina e densa ( $\varnothing$ cerca de $0,02 \mathrm{~mm},<1 \mathrm{dp}$ ), os intervalos finamente reticulados, adensada perto da linha frontal; na metade inferior da face mais grossa $(0,04-0,05 \mathrm{~mm})$ e esparsa (até $3 \mathrm{dp}$ ), os intervalos lisos; nas áreas paroculares inferiores os intervalos lisos até as fóveas faciais; área supraclipeal quase sem pontos; no clípeo um pouco mais grossa e densa que nas áreas paroculares; na área lisa ao lado dos ocelos laterais os intervalos maiores que o $\varnothing$ dos pontos; nas genas e no vértice fina, os intervalos lisos até finamente micro-reticulados ( $>1 \mathrm{dp}$ ); no mesoscuto um pouco mais fina que na fronte (cerca de $0,02 \mathrm{~mm},<1 \mathrm{dp}$ ), os intervalos fortemente reticulados; no escutelo mais grossa e muito esparsa, os intervalos lisos; nos mesepisternos esparsa (até $2 \mathrm{dp}$ ), os intervalos fortemente reticulados; os cantos posteriores do propódeo quase sem pontos e com retículo forte; na face posterior adensada para baixo; T1 quase sem pontos, liso e brilhante inclusive da depressão marginal; T2 e seguintes com pontuação fina, adensada para a base, muito esparsa para a depressão marginal, os intervalos finamente reticulados, quase lisos; em T5 mais grossa e mais esparsa; as depressões marginais de todos os tergos quase lisas, com retículo extremamente fraco.

Comprimento do olho $0,98 \mathrm{~mm}$, largura $0,5 \mathrm{~mm}$; olhos convergentes para baixo, distâncias interorbitais: superior $1,0 \mathrm{~mm}$, média $0,96 \mathrm{~mm}$, inferior $0,89 \mathrm{~mm}$; distância interalveolar $0,22 \mathrm{~mm}$; alveolorbital $0,25 \mathrm{~mm}$; alveolocelar $0,4 \mathrm{~mm}$; $\varnothing$ alvéolo $0,13 \mathrm{~mm}$; interocelar $0,2 \mathrm{~mm}$; ocelorbital $0,3 \mathrm{~mm}$; $\varnothing$ ocelo médio $0,12 \mathrm{~mm}$; comprimento das suturas subantenais: a externa $0,4 \mathrm{~mm}$, a interna $0,3 \mathrm{~mm}$, largura da área subantenal $0,13 \mathrm{~mm}$; comprimento do clípeo $0,44 \mathrm{~mm}$, largura $0,86 \mathrm{~mm}$; clipeocelar $0,75 \mathrm{~mm}$; linha frontal sulciforme entre os alvéolos, desaparecendo para cima; fóvea facial estreita e longa, bem marcada, lisa, comprimento $0,26 \mathrm{~mm}$ largura $0,1 \mathrm{~mm}$; largura do labro $0,48 \mathrm{~mm}$, placa labral estreitada para o ápice, lisa, sem rúgulas, comprimento $0,22 \mathrm{~mm}$, largura $0,26 \mathrm{~mm}$; escapo: comprimento e $\varnothing$ máximo $0,42 \mathrm{~mm}, 0,12 \mathrm{~mm}$; flagelo clavado, comprimento dos três primeiros flagelômeros $0,13 \mathrm{~mm}, 0,08 \mathrm{~mm}, 0,08 \mathrm{~mm}, \varnothing$ do terceiro $0,13 \mathrm{~mm}$; maior $\varnothing 0,19$ $\mathrm{mm}$; flagelo e pedicelo juntos $1,4 \mathrm{~mm}$; 6 a 7 hâmulos; fêmur médio em arco levemente anguloso; basitarso médio cerca de três vezes mais longo que largo $(0,46$ : $0,16 \mathrm{~mm}$ ); área basal do propódeo triangular, um pouco acuminada, com uma carena média forte e comprida, alcançando o canto posterior do propódeo, carenas laterais curtas, semi-paralelas; T2 com fóveas laterais pouco evidentes, comprimento 0,18 $\mathrm{mm}$, largura $0,09 \mathrm{~mm}$; placa pigidial rebordada com uma carena grossa e finas carenas transversais.

Macho não conhecido.

Holótipo fềmea. Brasil, Rio Grande do Sul: São Francisco de Paula (Pró-Mata) 25-XI-1995, B. Harter leg. (DZUP). Parátipo de Cruz Alta, 03-XI-1990, B. Blochtein leg., 1 fêmea (LPB); parátipo de Caçapava do Sul (Minas do Camaquã), 11-XI-1990, C. Schlindwein leg., 1 fêmea (MZUSP); parátipo de Caçapava do Sul 
(Minas do Camaquã), 14-XI-1990, C. Schlindwein leg., 1 fềmea (UFPB); parátipo de Caçapava do Sul (Guaritas), 26-X-1991, C. Schlindwein leg., 1 fêmea, (LSEA).

Flores visitadas. Oxalis niederleinii Knuth, Oxalis sp. (Oxalidaceae), Mecardonia tenella (Scrophulariaceae).

Sazonalidade. Outubro, novembro.

Distribuição geográfica. BRASIL, Rio Grande do Sul, Serra do Sudeste, Serra Geral, Planalto médio.

Etimologia. politus $($ latim $)=$ polido, brilhante. $\mathrm{O}$ nome refere-se ao tegumento brilhante em T1.

\section{Panurgillus reticulatus sp.n.}

Diagnose. Retículo forte no corpo inteiro; mesoscuto com pontuação esparsa e pilosidade relativamente comprida; pernas inteiramente pretas; placa labral larga. Machos sem desenhos amarelos.

Holótipo fêmea. Comprimento total aproximado $6,3 \mathrm{~mm}$; asa anterior 4,9 $\mathrm{mm}$; largura da cabeça $1,86 \mathrm{~mm}$; comprimento da cabeça $1,56 \mathrm{~mm}$; largura do metasoma $1,95 \mathrm{~mm}$.

Tegumento preto com o flagelo amarelo pálido por baixo; tégula amarelada, translúcida, o terço anterior escuro, com pontos pilígeros; asas subhialinas com veias e pterostigma pardo-méleos, uma pequena mancha amarela na extemidade basal da costa; tíbias inteiramente pretas; depressões marginais dos tergos fracamente translúcidas.

Pilosidade esbranquiçada, esparsa e rala; relativamente comprida e plumosa no vértice, no escutelo, no metanoto e nos mesepisternos (cerca de $0,25 \mathrm{~mm}$ ); no mesoscuto um pouco mais curta $(0,18 \mathrm{~mm})$; por baixo nos mesepisternos com pêlos finos, às vezes um pouco recurvados; nos flancos do propódeo como no escutelo; escopa com pêlos brancos anteriormente, pálidos atrás, em parte escuros na base, com cerdas não plumosas relativamente esparsas, comprimento $0,48 \mathrm{~mm}$; nos tergos muito rala e curta; em T5 algumas cerdas pretas na base, translúcidas no ápice, 0,42 $\mathrm{mm}$ e com curta franja apical escura; pêlos no escapo até $0,12 \mathrm{~mm}$.

Pontuação disfarçada pela densa reticulação na cabeça e no mesosoma; na face bastante uniforme, $\varnothing$ cerca de $0,04 \mathrm{~mm}$, esparsa (3-5dp), mais densa perto da linha frontal e dos ocelos; área supraclipeal quase sem pontos, ficando um pouco mais brilhante entre os alvéolos; no vértice e nas genas esparsa; no mesoscuto, escutelo e metanoto fina (cerca de $0,02 \mathrm{~mm}$ ) e esparsa (cerca de $3 \mathrm{dp}$ ), pontos pouco visíveis; nos flancos do propódeo mais evidente, com algumas rúgulas transversais na parte inferior; nos tergos muito fina, na base mais evidente, esparsa, o retículo menos desenvolvido; em T2 1-2dp, T1 um pouco mais esparsa, em T5 mais grossa e esparsa, os intervalos reticulados; depressões marginais reticuladas, retículo desaparecendo em direção da margem apical.

Comprimento do olho $1,12 \mathrm{~mm}$, largura $0,6 \mathrm{~mm}$; distâncias interorbitais: superior $1,2 \mathrm{~mm}$, média $1,16 \mathrm{~mm}$, inferior $1,12 \mathrm{~mm}$; distância interalveolar 0,32 $\mathrm{mm}$; alveolorbital $0,3 \mathrm{~mm}$; alveolocelar $0,44 \mathrm{~mm}$; $\varnothing$ alvéolo $0,12 \mathrm{~mm}$; interocelar $0,33 \mathrm{~mm}$; ocelorbital $0,32 \mathrm{~mm} ; \varnothing$ ocelo médio $0,14 \mathrm{~mm}$; carenas radiantes em volta 
do ocelo médio, finas, curtas; comprimento das suturas subantenais: a externa 0,48 $\mathrm{mm}$, a interna $0,34 \mathrm{~mm}$, largura da área subantenal $0,16 \mathrm{~mm}$; comprimento do clípeo $0,5 \mathrm{~mm}$, largura $1,08 \mathrm{~mm}$; clipeocelar $0,85 \mathrm{~mm}$; linha frontal careniforme chegando até o ocelo médio; fóvea facial estreita e longa, comprimento $0,35 \mathrm{~mm}$, largura 0,10 $\mathrm{mm}$, bem marcada, com alguns pêlos; largura do labro $0,58 \mathrm{~mm}$, placa labral relativamente curta, subtruncada, lisa e com vestígios de rúgulas longitudinais na metade basal, comprimento $0,24 \mathrm{~mm}$, largura $0,36 \mathrm{~mm}$; escapo: comprimento e $\varnothing$ máximo $0,44 \mathrm{~mm}, 0,14 \mathrm{~mm}$; flagelo clavado, comprimento dos três primeiros flagelômeros $0,18 \mathrm{~mm}, 0,10 \mathrm{~mm}, 0,09 \mathrm{~mm}, \varnothing$ do terceiro $0,14 \mathrm{~mm}$, maior $\varnothing 0,18$ $\mathrm{mm}$; flagelo e pedicelo juntos cerca de $1,6 \mathrm{~mm}$; 8 a 9 hâmulos; fêmur médio com ângulo; basitarso médio duas até três vezes mais longo que largo $(0,6: 0,24 \mathrm{~mm})$; área basal do propódeo com pêlos compridos, uma carena média forte alcançando a margem posterior do propódeo e várias carenas laterais, subparalelas na sua metade anterior, irregulares detrás; T2 com fóveas laterais pouco evidentes, rasas, comprimento $0,3 \mathrm{~mm}$, largura $0,12 \mathrm{~mm}$; placa pigidial fracamente rebordada, lisa e com depressões ao lado da carena média.

Alótipo, macho: Comprimento total aproximado 5,2 mm; asa anterior 4,4 $\mathrm{mm}$; largura da cabeça $1,68 \mathrm{~mm}$; comprimento da cabeça $1,5 \mathrm{~mm}$; largura do metasoma $1,6 \mathrm{~mm}$.

Tegumento preto com as antenas amareladas a partir do terceiro flagelômero; tégula ocre, pouco translúcida, com retículo forte; asas subhialinas com veias e pterostigma castanhos, base das veias amarela; tíbias em geral pretas; tarsos castanhos; depressões marginais dos tergos fracamente translúcidas.

Pilosidade esbranquiçada, esparsa, relativamente comprida e plumosa na cabeça, no escutelo, no metanoto e nos mesepisternos (até $0,25 \mathrm{~mm}$ ); no mesoscuto um pouco mais curta $(0,14 \mathrm{~mm})$; lado ventral dos mesepisternos sem pêlos em gancho; pilosidade nos tergos muito rala e curta; alguns pêlos finos, adpressos nos esternos, pouco evidentes; pêlos no escapo longos, até $0,24 \mathrm{~mm}$.

Pontuação disfarçada pela densa reticulação na cabeça e no mesosoma, muito parecida com a fêmea; no mesoscuto e escutelo fina (cerca de $0,02 \mathrm{~mm}$ ) e esparsa, os intervalos até $3 \mathrm{dp}$, no metanoto densa $(<1 \mathrm{dp})$; nos mesepisternos esparsa, adensada para cima; nos metepisternos com retículo muito forte; nos flancos do propódeo mais evidente, com algumas rúgulas transversais na parte inferior; nos tergos muito fina, pouco evidente, esparsa, o retículo bem desenvolvido, porém mais fraca que no mesosoma; em T2 1-2dp, em T1 um pouco mais esparsa; depressões marginais reticuladas.

Comprimento do olho $0,98 \mathrm{~mm}$, largura $0,52 \mathrm{~mm}$; olhos levemente convergentes para baixo, distâncias interorbitais: superior $1,05 \mathrm{~mm}$, média $1,02 \mathrm{~mm}$, inferior $0,98 \mathrm{~mm}$; distância interalveolar $0,24 \mathrm{~mm}$; alveolorbital $0,26 \mathrm{~mm}$; alveolocelar $0,42 \mathrm{~mm}$; $\varnothing$ alvéolo $0,12 \mathrm{~mm}$; interocelar $0,24 \mathrm{~mm}$; ocelorbital $0,32 \mathrm{~mm} ; \varnothing$ ocelo médio $0,14 \mathrm{~mm}$; carenas radiantes em volta do ocelo médio, finas e curtas; comprimento das suturas subantenais: a externa $0,44 \mathrm{~mm}$, a interna $0,34 \mathrm{~mm}$, largura da área subantenal $0,14 \mathrm{~mm}$; comprimento do clípeo $0,48 \mathrm{~mm}$, largura $0,9 \mathrm{~mm}$; clipeocelar $0,72 \mathrm{~mm}$; linha frontal careniforme até o ocelo médio; fóvea facial pequena, comprimento $0,22 \mathrm{~mm}$, largura $0,08 \mathrm{~mm}$; largura do labro $0,48 \mathrm{~mm}$, placa labral lisa e com vestígios de rúgulas longitudinais na metade basal, os lados 
convergentes, o bordo anterior em arco rebaixado, comprimento $0,22 \mathrm{~mm}$, largura $0,3 \mathrm{~mm}$; escapo: comprimento e $\varnothing$ máximo $0,4 \mathrm{~mm}, 0,14 \mathrm{~mm}$; flagelo clavado, comprimento dos três primeiros flagelômeros $0,12 \mathrm{~mm}, 0,12 \mathrm{~mm}, 0,12 \mathrm{~mm}, \varnothing$ do terceiro $0,15 \mathrm{~mm}$, maior $\varnothing 0,18 \mathrm{~mm}$; flagelo e pedicelo juntos cerca de $1,88 \mathrm{~mm}$; 7 hâmulos; basitarso médio 4 até 5 vezes mais longo que largo $(0,56: 0,12 \mathrm{~mm})$; área basal do propódeo como na fêmea; T2 com fóveas laterais pouco evidentes, comprimento $0,12 \mathrm{~mm}$, largura $0,06 \mathrm{~mm}$.

Holótipo fêmea. Brasil, Rio Grande do Sul: São Francisco de Paula (Pró-Mata), 25-XI-1995, Birgit Harter leg.; alótipo, macho, Rio Grande do Sul: Osório (RS 486), 16-X-1992, I. Alves dos Santos leg.. Parátipos de Viamão, 25-IX-1990, C. Schlindwein leg., três fêmeas; Osório (RS 486), 22-X-1991, I. Alves dos Santos leg., duas fêmeas; 24-X-1992, duas fêmeas (DZUP); parátipos com os mesmos dados do holótipo, 1 fêmea; da mesma localidade e coletor, 08-XI-1995, 4 fêmeas; Viamão, 25-IX-1990, B. Blochtein leg., 5 fêmeas; C. Schlindwein leg., 3 fêmeas; Santana da Boa Vista, 30-IX-1990, C. Schlindwein leg., 1 fềmea; Caçapava do Sul, 10-X-1989, D. Wittmann, leg., duas fềmeas; Osório, 22-X-1991, I. Alves dos Santos leg., 7 fềmeas; 16-X-1992, 1 fềmea; 24-X-1992, duas fêmeas; 10-XI1993, 7 fêmeas (LPB); parátipos com os mesmos dados do holótipo, 1 fềmea; Osório, 22-X-1991, I. Alves dos Santos leg., duas fềmeas; Viamão, 25-IX-1990, B. Blochtein leg., duas fêmeas (FZB); parátipos de Osório, 22-X-1991, I. Alves dos Santos leg., 3 fêmeas; Viamão, 25-IX-1990, C. Schlindwein. leg., 2 fêmeas (MZUSP); parátipos com os mesmos dados do holótipo, 1 fêmea; da mesma localidade e coletor, 08-XI-1995, 1 fêmea; Viamão, 25-IX-1990, C. Schlindwein leg., 4 fêmeas; Caçapava do Sul (Guaritas), 08-X-1993, C. Schlindwein, leg., três fềmeas (UFPB); parátipos de Viamão, 25-IX-1990, C. Schlindwein leg., 1 fêmea; Caçapava do Sul (Guaritas), 26-X-1991, C. Schlindwein leg., 1 fêmea; Osório, 10-XI-1993, I. Alves dos Santos leg., 1 fêmea (LSEA).

Flores visitadas. Oxalis brasiliensis Loddiges, $O$. corniculata L., $O$. debilis H.B.K., O. linarantha Lourteig, O. floribunda Lehmann, O. niederleinii Knuth (Oxalidaceae).

Sazonalidade. Setembro até novembro.

Distribuição geográfica. BRASIL, Rio Grande do Sul, Serra do Sudeste, Serra Geral, Litoral de Santa Catarina

Etimologia. reticulum dim. de retis $($ latim $)=$ rede. $\mathrm{O}$ nome refere-se à superfície reticulada do tegumento entre os pontos em quase todo o corpo.

Comentário. Depressões marginais dos tergos algumas vezes inteiramente pretas. Fêmeas parecidas com as de P. plumosulus.

\section{Panurgillus vagabundus (Cockerell) comb.n.}

Figs $2 a-b, 3 f, 4 d, 5 a$

Panurginus vagabundus Cockerell 1918. Entomol. News 29: 169-170.

Diagnose. Olhos paralelos; placa labral muito larga; tíbias anteriores e médias com uma mancha amarela na base; mesoscuto com pilosidade muito curta; pontuação nos tergos densa. Macho com clípeo amarelo menos os cantos laterais; mandíbulas amarelas menos uma mancha preta na base; fêmures com mancha 
amarela na extremidade apical; tíbia anterior com face anterior amarela, média com estria amarela, posterior com a metade basal amarela.

Fêmea. Comprimento total aproximado $6,25 \mathrm{~mm}$; asa anterior 4,6 mm; largura da cabeça $1,89 \mathrm{~mm}$; comprimento da cabeça $1,52 \mathrm{~mm}$; largura do metasoma $1,92 \mathrm{~mm}$.

Tegumento preto com o flagelo amarelo-pálido por baixo; tégula ocre, translúcida; asas subhialinas com veias e pterostigma méleos, uma mancha amarela na base da $\mathrm{C}+\mathrm{Sc}$; pequenas manchas amarelas na base das tíbias anteriores e médias; distitarsos dos três pares de pernas ocres; depressões marginais dos tergos escuras, ficando ligeiramente translúcidas no bordo posterior.

Pilosidade esbranquiçada, esparsa e rala; na face e nas genas até $0,2 \mathrm{~mm}$, no mesoscuto muito curta (cerca de $0,04 \mathrm{~mm}$ ), um pouco mais comprida e plumosa no pronoto, escutelo, metanoto e nos mesepisternos (até $0,16 \mathrm{~mm}$ ); pronoto e lóbulos pronotais com pêlos curtos, plumosos; lado ventral dos mesepisternos sem pêlos em gancho; escopa com cerdas brancas, não plumosas, esparsas (Fig. 5a), comprimento cerca de $0,5 \mathrm{~mm}$; na área basal do propódeo extremamente curta; no T5 amarelada, com algumas cerdas pretas misturadas (cerca de $0,35 \mathrm{~mm}$ ); T5 com curta franja apical preta; pêlos no escapo até $0,14 \mathrm{~mm}$.

Pontuação na fronte, nas áreas paroculares e subantenais muito densa $(<1 / 2 \mathrm{dp}, \varnothing$ cerca de $0,03 \mathrm{~mm})$; no clípeo e área supraclipeal perto do clípeo mais esparsa ( $2 \mathrm{dp}$ ) e grossa $(\varnothing$ até $0,05 \mathrm{~mm}$ ), intervalos com alguns micropontos intercalados; nas genas e no vértice densa; na cabeça os intervalos entre os pontos lisos; no mesoscuto mais fina e esparsa que na cabeça (cerca de $0,02 \mathrm{~mm}, 1-2 \mathrm{dp}$ ), os intervalos reticulados; no escutelo e metanoto mais grossa e um pouco mais densa, com micropontos intercalados; propódeo sem pontos junto à área basal, porém com retículo, pontos finos e esparsos para baixo, passando para micropontuado nos flancos; em T1 fina (cerca de 0,02 mm), relativamente densa ( $\leq 1 \mathrm{dp}$ ), os intervalos micro-reticulados; em T2 mais fina, adensada na base, em T3 e T4 tornando-se mais fina e esparsa; T2-T4 com intervalos quase lisos; distância entre os pontos 1-2dp; em T5 mais grossa e esparsa, os intervalos reticulados; depressões marginais micropontuadas.

Comprimento do olho $1,08 \mathrm{~mm}$, largura 0,56 ; olhos paralelos, distâncias interorbitais: superior $1,24 \mathrm{~mm}$, média $1,22 \mathrm{~mm}$, inferior $1,2 \mathrm{~mm}$; distância interalveolar $0,36 \mathrm{~mm}$; alveolorbital $0,3 \mathrm{~mm}$; alveolocelar $0,48 \mathrm{~mm}$; $\varnothing$ alvéolo $0,17 \mathrm{~mm}$; interocelar $0,3 \mathrm{~mm}$; ocelorbital $0,21 \mathrm{~mm}$; $\varnothing$ ocelo médio $0,14 \mathrm{~mm}$; comprimento das suturas subantenais: a externa $0,36 \mathrm{~mm}$, a interna $0,3 \mathrm{~mm}$, largura da área subantenal $0,15 \mathrm{~mm}$; comprimento do clípeo $0,54 \mathrm{~mm}$, largura $1,06 \mathrm{~mm}$; clipeocelar $0,78 \mathrm{~mm}$; linha frontal sulciforme, desaparecendo próximo ao ocelo médio; fóvea facial (Fig. 2b) com a sua largura maior na metade superior, comprimento $0,4 \mathrm{~mm}$, largura $0,11 \mathrm{~mm}$, lisa, bem marcada; largura do labro $0,6 \mathrm{~mm}$, placa labral lisa, com vestígios de micro-rúgulas longitudinais na metade superior, quase truncada (Fig. 3 f), comprimento $0,22 \mathrm{~mm}$, largura $0,36 \mathrm{~mm}$; comprimento e $\varnothing$ máximo do escapo $0,48 \mathrm{~mm}, 0,16 \mathrm{~mm}$; flagelo ligeiramente clavado, comprimento dos três primeiros flagelômeros $0,16 \mathrm{~mm}, 0,09 \mathrm{~mm}, 0,1 \mathrm{~mm}, \varnothing$ do terceiro $0,14 \mathrm{~mm}$, maior $\varnothing 0,19$ $\mathrm{mm}$; flagelo e pedicelo juntos $1,76 \mathrm{~mm}$; 7-8 hâmulos; fêmur médio com o bordo 
inferior em curva ligeiramente angulosa (Fig. 4d); basitarso médio menos que duas vezes mais longo que largo $(0,38: 0,22 \mathrm{~mm})$; área basal do propódeo semilunar, com poucas carenas curtas, subparalelas, não alcançando o canto posterior do propódeo, as médias não mais fortes que as laterais; T2 com fóveas laterais pouco evidentes, rasas, comprimento $0,34 \mathrm{~mm}$, largura $0,1 \mathrm{~mm}$; placa pigidial rebordada, com estrias transversais.

Alótipo, macho: Comprimento total aproximado $4,8 \mathrm{~mm}$; asa anterior $4 \mathrm{~mm}$; largura da cabeça 1,62 $\mathrm{mm}$; comprimento da cabeça $1,34 \mathrm{~mm}$; largura do metasoma $1,42 \mathrm{~mm}$.

Tegumento preto com o clípeo amarelo, menos os cantos laterais e duas pequenas manchas pretas, uma cada lado, perto da fóvea tentorial anterior; mandíbulas amarelas menos uma pequena mancha preta na base, as margens transparentes; flagelo amarelado; tégula translúcida, amarelada; asas subhialinas com veias e pterostigma castanhos, a base da $\mathrm{C}+\mathrm{Sc}$ amarela; extremidade apical dos fêmures com uma pequena mancha amarela; tíbia anterior amarela, castanha por trás; tíbia média com uma estria amarela na extremidade basal; tíbia posterior com a metade basal amarela, inclusive a placa basitibial; tarsos dos três pares de pernas amarelos; depressões marginais dos tergos escuras, pouco transparentes.

Pilosidade esbranquiçada, esparsa, rala; na face, vértice e genas até $0,2 \mathrm{~mm}$; no mesoscuto e no escutelo curta (cerca de $0,04 \mathrm{~mm}$ ); mais comprida e plumosa no metanoto, nos mesepisternos e flancos do propódeo (até $0,2 \mathrm{~mm}$ ); pêlos curtos, plumosos, na área basal do propódeo; no T6 amarelada; pêlos no escapo curtos, até $0,08 \mathrm{~mm}$.

Pontuação muito densa em toda cabeça $(<1 \mathrm{dp}, \varnothing 0,02-0,03 \mathrm{~mm})$; área supraclipeal com algumas rúgulas curtas longitudinais; no mesoscuto um pouco mais fina que na cabeça (cerca de $0,02 \mathrm{~mm}$ ) e esparsa (cerca de $1 \mathrm{dp}$ ), os intervalos suavemente reticulados, porém com brilho; no escutelo e metanoto mais grossa, com micropontos intercalados; nos mesepisternos como no escutelo, os intervalos fortemente retículados; nos metepisternos muito fina e densa; propódeo sem pontos junto à área basal, porém com retículo, pontos finos para baixo, nos flancos com retículo hexagonal; nos tergos fina, $\varnothing$ diminuindo de T1 para T5, os intervalos lisos até finamente reticulados, aproximadamente 1dp; em T6 mais grossa; depressões marginais micropontuadas, desaparecendo no T4, T5 e T6.

Comprimento do olho $0,94 \mathrm{~mm}$, largura $0,5 \mathrm{~mm}$; olhos convergentes para baixo, distâncias interorbitais: superior $1,12 \mathrm{~mm}$, média $0,98 \mathrm{~mm}$, inferior $0,9 \mathrm{~mm}$; distância interalveolar $0,26 \mathrm{~mm}$; alveolorbital $0,22 \mathrm{~mm}$; alveolocelar $0,42 \mathrm{~mm}$; $\varnothing$ alvéolo $0,12 \mathrm{~mm}$; interocelar $0,26 \mathrm{~mm}$; ocelorbital $0,32 \mathrm{~mm}$; $\varnothing$ ocelo médio 0,14 $\mathrm{mm}$; suturas subantenais pouco evidentes, a externa $0,34 \mathrm{~mm}$, a interna $0,24 \mathrm{~mm}$, largura da área subantenal $0,12 \mathrm{~mm}$; comprimento do clípeo $0,48 \mathrm{~mm}$, largura 0,8 $\mathrm{mm}$; clipeocelar $0,66 \mathrm{~mm}$; linha frontal pouco evidente; fóvea facial lisa, bem marcada, mais larga no terço superior, comprimento $0,22 \mathrm{~mm}$, largura $0,06 \mathrm{~mm}$; largura do labro $0,42 \mathrm{~mm}$, placa labral lisa, subretangular, com micro-rúgulas radiantes no terço superior, pouco evidentes, comprimento $0,18 \mathrm{~mm}$, largura 0,28 $\mathrm{mm}$; comprimento e $\varnothing$ máximo do escapo $0,32 \mathrm{~mm}, 0,18 \mathrm{~mm}$; comprimento dos três primeiros flagelômeros $0,12 \mathrm{~mm}, 0,1 \mathrm{~mm}, 0,12 \mathrm{~mm}, \varnothing$ do terceiro $0,16 \mathrm{~mm}$, 
maior $\varnothing 0,16 \mathrm{~mm}$; flagelo e pedicelo juntos $1,72 \mathrm{~mm}$; 7 hâmulos; basitarso médio $>$ três vezes mais longo que largo $(0,36: 0,11 \mathrm{~mm})$; área basal do propódeo semilunar, com poucas carenas fracas, subparalelas, interrompidas, não alcançando o canto posterior do propódeo, as médias não mais fortes que as laterais; T2 com fóveas laterais pouco evidentes, comprimento $0,14 \mathrm{~mm}$, largura $0,06 \mathrm{~mm}$.

O holótipo encontra-se no US National Museum. Foram vistos por J.S. Moure uma fêmea e um macho desta espécie na Universidade de Nebraska e um cótipo de Carcarañá (Argentina) no US National Museum, comparados com material da coleção de Curitiba.

A redescrição baseia-se em abelhas coletadas no Rio Grande do Sul: Fêmea. Brasil, Rio Grande do Sul: Caçapava do Sul (Guaritas), 21-X-1994, C. Schlindwein leg.; macho: mesma localidade e coletor, 25-X-1991; de outras localidades: ARgEnTINA, Buenos Aires: um macho, 13-II-1938, M.M. Senkute leg.; San Isidro, Buenos Aires, três machos X-1957, H. Walz leg.; Campana, Buenos Aires três fêmeas, XII-1955, H. Walz leg. (DZUP). Vários exemplares do Rio Grande do Sul: Caçapava do Sul e Guaritas, coletados por Schlindwein nos meses de outubro e novembro (LPB, FZB, MZ, UFPB e LSEA).

Flores visitadas. Cerastium commersonianum Ser. (Caryophyllaceae); Glechon thymoides Spreng. (Lamiaceae), Nothoscordum inodorum (Soland.) Nichol. (Liliaceae), Abutilon malachroides St. Hil. \& Naud., A. panciflorum St. Hil., A terminale (Cav.) St. Hil., Modiolastrum lateritium (Hook) Krapovickas, Sida dubia St. Hil. \& Naud. (Malvaceae). Portulaca cryptopetala Speg. (Portulacaceae).

Sazonalidade: Outubro, novembro.

Distribuição geográfica. BRASIL, Rio Grande do Sul, Serra do Sudeste; Argentina, Buenos Aires até Carcarañá.

Comentário. Fêmeas de $P$. vagabundus são semelhantes às fêmeas de $P$. hamatus; $P$. vagabundus difere pela pontuação mais densa nas áreas supraclipeais, subantenais e paroculares; olhos paralelos; área basal de propódeo com rúgulas curtas e fracas, a rúgula média não maior que as outras e não alcançando a face posterior do propódeo; pontuação fina nos tergos, porém mais forte que a de $P$. hamatus, no primeiro tergo pontos mais esparsos perto da depressão marginal, porém presentes, os intervalos com retículo; pontuação no mesoscuto mais esparsa; fóvea facial mais larga na metade superior pêlos retos, não plumosos no lado ventral do mesepisterno (em gancho em $P$. hamatus).

\section{Chave para identificação das fêmeas de Panurgillus}

1. Lóbulos pronotais com mancha amarela; fêmur mediano com dente ventral no

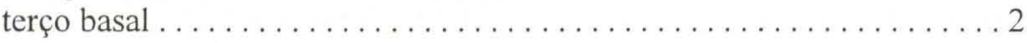

- Lóbulos pronotais pretos; fêmur mediano sem dente ventral podendo formar ângulo marcado no terço basal . ........................ 4

2. Clípeo com mancha amarela; lado ventral dos mesepisternos com pêlos retos . . pereziae

- Clípeo preto; mesepisternos por baixo com pêlos em gancho. . 3 
3. Área ocelorbital com pontuação uniforme muito fina e densa $(<1 \mathrm{dp})$; dois terços das mandíbulas amarelas . . . . . . . . . . . . . . . . formosus

- Área ocelorbital com pontuação esparsa (2-3dp); as mandíbulas castanho-escuras

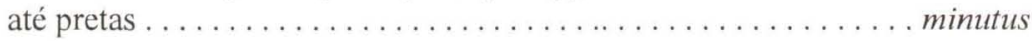

4. Clípeo opaco, reticulado entre os pontos; extremidade basal das tíbias anteriores sem mancha amarela . . . . . . . . . . . . . . . . . . . . 5

- Clípeo liso, brilhante entre os pontos; extremidade basal das tíbias anteriores com

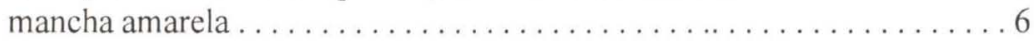

5. Mesoscuto com pilosidade muito curta, menos da metade do $\varnothing$ máximo do escapo, com pontuação densa, os intervalos cerca de $1 \mathrm{dp}$; carena frontal forte; 9 a 10 hâmulos . ..................... malvacearum

- Mesoscuto com pilosidade mais longa que o $\varnothing$ máximo do escapo, com pontuação esparsa, distância entre os pontos $>2 \mathrm{dp}$; carena frontal fraca; 8 a 9 hâmulos reticulatus

6. Mesoscuto com pontuação muito esparsa, distância entre os pontos $>2 \mathrm{dp}$; mesoscuto com pilosidade longa, $\varnothing$ ao máximo do escapo (em harterae

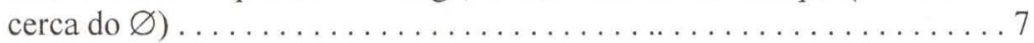

- Mesoscuto com pontuação densa, distância entre os pontos $<2 \mathrm{dp}$, com pilosidade

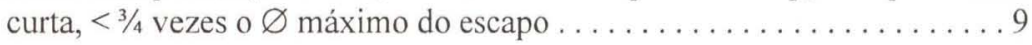

7. Basitarso médio estreito, quase quatro vezes mais longo do que largo; fêmur médio em curva contínua, não formando ângulo; basitarsos amarelos; $10 \mathrm{a}$ 12 hâmulos . . . . . ..........................flavitarsis

-. Basitarso médio alargado, menos que três vezes mais longo do que largo; fêmur médio formando ângulo pronunciado; basitarsos castanhos ou pretos . . . 8

8. Antenas inteiramente pretas; comprimento dos pêlos no mesoscuto semelhante ao $\varnothing$ máximo do escapo; sulco evidente acima do ocelo médio; 9 a 11 hâmulos ................................. harterae

-. Antenas com o flagelo amarelo por baixo; comprimento dos pêlos no mesoscuto mais que duas vezes o $\varnothing$ máximo do escapo; acima do ocelo um sulco inconspícuo; 7 a 9 hâmulos ....................... plumosulus

9. Pontuação densa e funda em todo o corpo, bastante uniforme na cabeça e mesosoma $(<1 \mathrm{dp})$; densa também no disco do T1; T2 com fóveas laterais fortes, profundas . .............................. holostictus

- Pontuação não uniforme densa e profunda na cabeça e mesosoma; T2 com fóveas laterais pouco evidentes, rasas . .................... 10

10. T1 com os intervalos mate-reticulados; as mandíbulas de cor castanha ....... eustictus

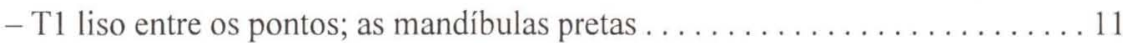

11. Lado ventral dos mesepisternos com pilosidade normal, sem pêlos em gancho . vagabundus

- Lado ventral dos mesepisternos com pêlos em gancho ................ 12 
12. Mesoscuto com os intervalos entre os pontos brilhantes, os pontos muito finos $(<0,02 \mathrm{~mm})$; nas asas posteriores com 8 a 9 hâmulos . . . . . . guariticola

- Mesoscuto com os intervalos reticulados entre os pontos; nas asas posteriores com 6 a 7 hâmulos . . . . . . . . . . . . . . . . . . . . . . . . . 13

13. T1 quase sem pontos, liso; intervalos em T2 1-2dp, finamente reticulados;

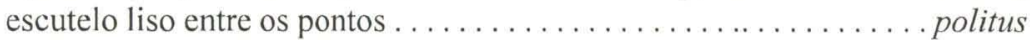

- T1 pontuado, os intervalos lisos, cerca de 1-2dp; T2 como T1; escutelo reticulado

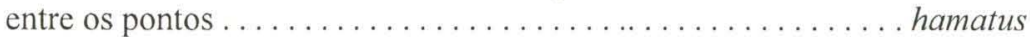

\section{Chave para identificação dos machos de Panurgillus}

1. Cabeça sem desenhos amarelos . . . . . . . . . . . . . . . . . 2

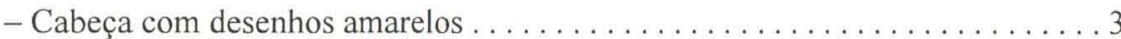

2. Placa labral profundamente emarginada, formando dois dentes triangulares ....

- Placa labral subretangular, não emarginada . . . . . . . . . . . . reticulatus

3. Labro e área supraclipeal amarelos . . . . . . . . . . . . . formosus

- Labro e área supraclipeal pretos . . . . . . . . . . . . . . . . . . . 4

4. Placa labral triangular . . . . . . . . . . . . . . . . . minutus

- Placa labral subretangular . . . . . . . . . . . . . . . . . . . 5

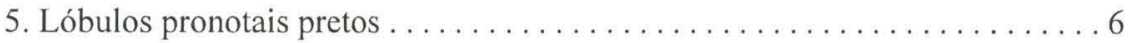

- Lóbulos pronotais amarelos $\ldots \ldots \ldots \ldots \ldots \ldots \ldots \ldots \ldots \ldots \ldots \ldots$

6. Antenas inteiramente pretas . . . . . . . . . . . . . . . harterae

- Antenas amareladas . . . . . . . . . . . . . . . . . vagabundus

7. Áreas paroculares e clípeo amarelos . . . . . . . . . . . . pereziae

- Áreas paroculares pretas; clípeo amarelo no centro e preto nos lados . . . hamatus

AGRADECIMENTOS. Isabel Alves dos Santos, Betina Blochtein, Birgit Harter, Birgit Hiller, Magali Hoffmann, Rainer Radtke, Sidia Witter Freitas, Dieter Wittmann coletaram parte do material aqui estudado. As fotos de SEM foram feitas com a ajuda de Horst Schoppmann. Mardiore Pinheiro e Viviane Goulart auxiliaram na confecção das pranchas fotográficas. $\mathrm{O}$ manuscrito foi revisado por Betina Blochtein. Este trabalho foi financiado pelo DFG (Deutsche Forschungsgemeinschaft) e CNPq.

\section{REFERÊNCIAS BIBLIOGRÁFICAS}

Cockerell, T.D.A. 1918. Some bees of the genus Panurginus (Hym.). Entomol. News 29: 169-171.

Cure, J.R. \& D. WitTManN. 1990. Callonychium petuniae, a new panurgine bee species (Apoidea, Andrenidae) oligolectic on Petunia (Solanaceae). Stud. Neotrop. Fauna Environ. 25 (3): 153-156.

Michener, C.D. 1979. Biogeography of the bees. Ann. Missouri Bot. Gard. 66 


\section{(3): $277-347$.}

MourE, J.S. 1997. A primeira constatação do gênero Arhysosage em cactáceas do Sul do Brasil (Hymenoptera: Apoidea). Revta bras. Zool. (no prelo).

Moure, J.S. \& J.M.F. CAmargo. 1989. Plebeia wittmanni, uma nova espécie de Meliponinae (Hymenoptera, Apidae) do sul do Brasil. Stud. Neotrop. Fauna Environ. 24 (1): 15-16.

Rozen, J.G. \& L. Ruz. 1995. South American panurgine bees (Apoidea: Andrenidae: Panurginae), part II. Adults, immature stages, and biology of Neffapis longilingua, a new genus and species with elongate glossa. Amer. Mus. Novitates 3136: 1-15.

Ruz, L. 1991. Classification and phylogenetic relationships of the panurgine bees: The Calliopsini and allies (Hymenoptera: Andrenidae). Univ. Kansas Sci. Bull. 54 (7): 209-256.

Ruz, L. \& J.G. Rozen. 1993. South American panurgine bees (Apoidea: Andrenidae: Panurginae), part I. Biology, mature larva, and description of a new genus and species. Amer. Mus. Novitates 3057: 1-12.

SCHLINDWEIN, C. 1995. Melittophilous plants, their pollen and flower visiting bees in southern Brazil. 2. Cactaceae. Biociências, Porto Alegre, 3 (2): 35-71.

URBAN, D. 1992. Gnathanthidium, gen. n. de Anthidiinae da América do Sul (Hymenoptera, Megachilidae). Revta bras. Zool. 9 (3/4): 337-343.

- 1995a. Espécies novas de Paracolletini e Panurginae do Sul do Brasil e Argentina (Hymenoptera, Apoidea). Revta bras. Zool. 12 (2): 397-405.

1995b. Espécies novas de Lanthanomelissa Holmberg e Lanthanella Michener \& Moure (Hymenoptera, Anthophoridae, Exomalopsinae). Revta bras. Zool. 12 (4): 767-777.

. 1996. Mielkeanthidium, gen.n. de Dianthidiini da América do Sul (Hymenoptera, Megachilidae). Revta bras. Zool. 13 (1): 121-125

Wittmann, D. \& M. Hoffmann. 1990. Bees of Rio Grande do Sul, southern Brazil (Insecta, Hymenoptera, Apoidea). Iheringia, Sér. Zool., 70: 17-43

Wittmann, D. \& C. Schlindwein. 1995. Melittophilous plants, their pollen and flower visiting bees in southern Brazil. 1 Loasaceae. Biociências, Porto Alegre, 3 (2): 19-34. 